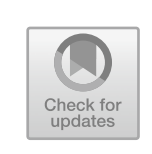

\title{
Pirate Narratives and the Colonial Atlantic
}

\subsection{The Buccaneer-Pirates: Articulations of Cultural Contact and Crisis, i678-i699}

\subsubsection{The Caribbean Scenario in the Late Seventeenth Century}

In the second half of the seventeenth century, the West Indies appeared as the most valuable colonial possessions of England and France": "The sugar islands provided their metropolitan powers with enormous wealth; they offered adventurous Britons and Frenchmen places to change and make fortunes; and, by affording places to which to transport criminals and vagrants, the islands served as relief valves for urban overcrowding and other social pressures" (Krise 1999, 7). The significance of the West Indies as the hub of empire (qua Eric Williams) in these decades is evidenced culturally by the abundance of travel and exploration narratives in transatlantic literature, starting in the seventeenth century; travel as "a sign of empire" was pertinent in "representations of the Elizabethan Sea Dogs, the swashbuckling pirates, and the fortune hunters" which "all reveal an underlying expansionist and exploitative motivation-a drive to seize whatever wealth was available" (7).

Travel and exploration literature constituted the Caribbean not only as a zone of cultural contact, "the first American frontier" (Mackie 2009,125 ) in which various populations and cultures-European, native, and African (American)-met, but also as a zone of crisis in political, economic, symbolic, and epistemological terms. The fact that piracy was

(C) The Author(s) 2020

A. Ganser, Crisis and Legitimacy in Atlantic American Narratives of Piracy, Maritime Literature and Culture, https://doi.org/10.1007/978-3-030-43623-0_2 
an important theme in this literature, with the pirate representing the ultimate outlaw-criminal on the one hand and a heroic model for a masculine, upwardly mobile colonial subjectivity representative of "the new moneyed economy" (Krise 1999, 13) on the other can be read as emblematic of the precariousness and criticality of colonial legitimacy. The Caribbean buccaneer-pirate, in various representations, highlighted the political and economic contest over the possession of and/or control over the West Indies, the struggle in the symbolic appropriation of these territories, and the uncontrollability of its agents, politically as well as culturally. In the last decades of the seventeenth century, narratives of piracy in the Americas such as Alexander Olivier Exquemelin's De Americaensche Zee-Roovers (1678; Engl. The Buccaneers of America, 1684), Basil Ringrose's “pot-boiler" (Munter and Grose 1986, 28) Dangerous Voyage and Bold Attempts of Captain Bartholomew Sharp (1685), William Dampier's A New Voyage Round the World (1697), or Lionel Wafer's $A$ Description of the Isthmus of Darien (1699), ${ }^{2}$ often set on the fringes of the Caribbean colonies (and further moving on to the Pacific coast via the Darién isthmus), voiced the complexity of cultural contact and translatio imperii maris as well as the uncontrollability of this process in the Americas. ${ }^{3}$

This chapter asks in what ways the pirate is represented as a figure of crisis in these narratives, a liminal figure between legitimate and illegitimate orders, between Europe and the Americas, wilderness and civilization, and clear-cut ethnic and national allegiances. I argue that in these texts, the pirate emerges as a critical, coastal figuration, a hybrid and fluid figure of contact and undecidability that, because of its liminal and paradoxical qualities, carried the potential of both questioning and affirming a burgeoning, yet highly precarious colonial system. In what follows, I thus explore to what extent pirates "were a reproach to plantocratic notions of law and order based on hereditary hierarchies of class, race, and gender" (Craton 1997, 53).

The spatial metaphor of the coast, structured by the temporalities of departure, arrival, and cultural encounter, highlights both the potentialities and limitations of contact between self and Other. It refers to a space in which semiotic systems become unstable and difference is negotiated anew as territorial orders are in suspension. Piratical narratives of this period demonstrate the increasing desire to discursively control this fluidity and to semantically incorporate the popular, transgressive figuration of the buccaneer-pirate into the imperial project. As such, the pirate 
book was increasingly appropriated by scientific discourses and obtained a substantial function in epistemological empire-building, the "second conquest" of the Americas (Bauer 2003, 3); by the end of the seventeenth century, pirate narratives constituted a "small but crucial niche in the publishing world" (Burgess 2014, 82).

The works under consideration are, in Ouellet's words, "marqués par cette 'crise de la conscience européenne' dont a si bien parlé Paul Hazard" $(2004,56),{ }^{4}$ the French historian whose seminal study La Crise de la conscience européenne, 1680-1715 (1935; Engl. The European Mind, 1953 ) diagnosed an intellectual and moral crisis $(\mathrm{xx})$ in this period of "revolution" (xv) in which "heresy" (xvii) in various forms articulated all the main ideas that would set the scene for the French Revolution. Emergent discourses of reason and right sought to replace duty and religion, the leading hermeneutic paradigms of European (especially French, English and Dutch) world-views. It is no coincidence that these countries were also the maritime powers dominating the Caribbean at the time; it is noteworthy, in the same vein, that Hazard starts his account by discussing the growing taste for travel and travel literature-he mentions English Barbary captivity narratives and Dampier's travel-books explicitly-as the seed of the new order in the early 1700s. It brought forth a change from stability to movement, paralleling a development from the 'classical' to the 'modern' mind and the influx of new ideas: "The exploration of the globe having resulted in discoveries that have destroyed many of the data on which ancient philosophy reposed, a new conception of things will inevitably be called for" (8). As perspectives changed with travel, so relativity was introduced as one of the "lessons derived from the idea of space" (11). In this "sea-change,"

... all the fundamental concepts, such as Property, Freedom, Justice and so on, were brought under discussion again as a result of the conditions in which they were seen to operate in far-off countries, in the first place because, instead of all differences being referred to one universal archetype, the emphasis was now on the particular, the irreducible, the individual; in the second, because notions hitherto taken for granted could now be checked in the light of facts ascertained by actual experience. (10)

An obsession with fact and experience, garnished with doubt (as the beginning of science) and probability, resulted in a new, Lockean empiricism that historians of science such as Barbara Shapiro and philosophers 
such as Edmund Husserl (in Die Krisis der europäischen Wissenschaften und die transzendentale Phänomenologie) have seen as a response, even outcome, of this crisis, even though few have emphasized the role of imperial travel as much as Hazard has. Philip Edwards characterizes the period by a "movement from experience to the written word, and on the mutations of the written word as it moves into print" $(1994,6)$.

Both Shapiro and Hazard draw a parallel between this epistemological crisis, with its scientific consequences, and the increasing predilection for a plain, prose style on the literary market (Shapiro 1983, 240-41). The appropriate genre for historiography, for instance, was no longer seen in poetry; metaphor was out of vogue, while factual, experiential, testimonial discourses were the reaction to doubt and skepticism, promising the highest point of certainty possible in the realm of science (29; absolute certainty was only possible in "God's knowledge" and "compelled assent" was a prerogative of logic and mathematics). Simplicity and clarity were associated with truth (247), and new literary forms such as the travel account "readily adopted the impartial presentation of matters of fact as their standard" (261): in this way, England developed $A$ Culture of Fact (Shapiro) that, however, is to a much greater extent transatlantically framed and entangled with England's imperial projects in the Caribbean than Shapiro's work suggests.

In the same period, the transatlantic pirate narrative undergoes a similar discursive transformation-from the presentation of spectacular buccaneers, mentioned by Hazard as counter-discursive, anti-rational, and speaking to the readers' appetites for pleasure and fancy $(1953,361-64)$, to the scientific, reasonable pirate-privateer whose works are published under the aegis of the British Royal Society. This is a gradual change, as all pirate narratives have to straddle the tension of their age between truth and pleasure, scientific and literary values (Shapiro 1983, 250). The genre of chorography, in which these texts can be located, offered a model that combined spectacular (travel) narrative and scientific observation, natural and human history, geography and ethnography (Shapiro references Dampier in her discussion of this genre, 1983, $301 \mathrm{n} .41$ ). Located to a large extent in the coastal zones of the American isthmus, the pirate chorography can be viewed both as a result of what Neil Rennie calls the "primitive colonialism" $(2013,110)$ of Caribbean buccaneers and as conditioned by a critical moment in the coloniality of English and European knowledge-formation that the genre sought to overcome. 


\subsubsection{The Buccaneer in Literature: Points and Counterpoints}

In the last three decades of the seventeenth century, the literature of piracy related to the Caribbean coast and the isthmus of Darién (in contemporary Panama) illustrates the instability of traditional categories of knowing and understanding. ${ }^{5}$ Fragmented, unstable, and unreliable voices and texts point to the epistemological crisis in the aftermath of cultural contact which resulted in a deep ambivalence between knowing and believing, intimacy and distance, authoritative gestures at consolidation and polyphonic disruption throughout the larger genre of early modern travel literature. The subgenre of expedition accounts by piratical explorers and proto-colonialists (who plundered the Americas without or with semi-official legitimation) is pervaded with a colonial violence marked by brutal subjugation and exploitation both physical and symbolical, a consequence mainly of European competition and conflict about the domination of the Americas. The pirate, who, as a legal subject, was characterized since antiquity as the enemy of all, especially of all nations, in contrast to the privateer (who was legitimized by an official letter of marque), is a liminal figure in these texts, moving between legitimacy and illegitimacy, between anti-mercantilist and proto-democratic counterculture and capitalist avant-garde. ${ }^{6}$

Narrative articulations of piracy vary significantly depending on genre; around 1700 the genres involved were mostly chorographic travel literature, ${ }^{7}$ gallows narratives, and sermons preached and printed on account of public executions of former pirates, especially in Puritan New England and London. All of them, however, no matter whether they were written by participants in semi-or illegal expeditions themselves or by local authorities trying to suppress piracy, share a characteristic polyphony and inner narrative tension as they negotiate a crisis of religious and moral authority (in the case of the sermons and gallows narratives), of political legitimacy, and of hermeneutic understanding and ordering.

Drawing on Said's method of contrapuntal reading, I argue that the polyphonic and fragmented nature of these texts presents a disruptive force in the imperial project, as polyphony is at the core of representations of cultural contact and crisis. While these narratives bear testimony of the attempt of colonizing alterity both through physical and symbolic acts of violation and appropriation, they are at the same time unable to fully mask the multiple, often resistant colonized voices. 
If the method of contrapuntal reading is applied to late seventeenthcentury literature, the empire is of course a fundamentally different one than that of the nineteenth, and thus also afflicts writing in a different way: while the nineteenth-century empire is politically and economically consolidated, seventeenth-century French and English imperialism is in the very process of constructing and legitimizing its own identity vis-àvis the Spanish predecessor, which had surpassed its zenith of colonial power already at the end of the 1500 s, via an articulation of difference: Protestant England was to emerge as a benevolent alternative to Catholic Spain, its mission of "terror" (Exquemelin [1678] 1969, 110) and the resulting genocidal cruelties toward the indigenous populations in the Americas, made popular through the Black Legend, la leyenda negra. ${ }^{8}$ Emphasizing difference between the Spanish and the English had been a discursive practice since the reign of Elizabeth I, who, in Ted Motohashi's ironical phrasing, "contrary to the evil Catholic King of Spain, truly cared for the well-being of the native population" $(1999,91)$, and continued in the representation of cultural contact and cooperation with indigenous populations in piratical chorographies (Kempe 2010, 179). Exquemelin reports that

... the Indians had hidden themselves in the forest, and the Spaniards could think of no better method than to bring in dogs to track them down. When any were found, the Spaniards hacked them to pieces and fed them to the hounds. Since that time, the Indians have been so terrified they dare not show themselves, and most of them have perished ... . I myself have seen caves in the mountains full of human bones ... . ([1678] $1969,48-49)$

Up to today, scholarship on piracy that simply reads the anti-Spanish Caribbean pirate as a figure of liberty (of proto-democracy, of free trade [Leeson, Storr], of egalitarianism, of anarchism [Kuhn], etc.) can be read in continuity with this Anglo-centric, nationalistic representation of the pirate as "a genuine emancipator" (Motohashi 1999, 91). The celebration of the pirate is thus also related to other cultural forms of missionary Protestant rhetoric in the context of colonial struggle and nation-building, as Nina Gerassi-Navarro (1999) has argued.

The process of English expansion in the Americas fascinated the English literate classes, who were in touch with colonial markets not only through monetary investment in commercial ventures but also via 
the consumption of Caribbean luxury goods such as sugar, tobacco, and cocoa-and of writings about the New World. Travel accounts, as Mary Louise Pratt argues in this context, "created the imperial order for Europeans 'at home' and gave them their place in it ... . [It] made imperial expansion meaningful and desirable to the citizenries of the imperial countries, even though the material benefits of the empire accrued mainly to the few" ([1992] 2008, 3). The literature of piracy, with its promise of economic potential, the mapping of certain American landscapes as Edenic, and an emphasis on "prizes" of gold and silver, participated in this best-selling genre (Arnold asserts that the book "quickly convinced the elites of northern Europe that the early successes of the buccaneers demonstrated that the Spanish Main was ... finally ripe for plucking," 2007, 10). The dissemination of the leyenda negra, rendering the Spanish nation the stereotypical embodiment of repression, degradation, brutality, religious and political intolerance, and intellectual and scientific backwardness (Powell [1971] 2008), was a strategy of legitimization to spur patriotic support of the English colonial project, which also motivated piratical ventures, as narratives of piracy highlight; in early English travel writing, Motohashi explains, the Spaniards are "excluded as a third term, because they have transgressed the 'universal'-European and Indian-code of human ethics" $(1999,94)$. Their defeat promised "a commonwealth based on an imaginary reciprocal accord and well-being" for both autochthonous populations and the English. In addition, the leyenda is an effective strategy to "designate Self as pure and as remote from hybridity as possible" by producing an "alien race close to its own European origin," emphasizing difference between the two: "This is the moralised logic behind the English colonising ideology as a latecomer to the expansionist venture." 9

The popularity of piratical literature might also be attributed, apart from its appeal to fantasy, colonial enthusiasm, and sensationalist appetite and credulity, to its coincidence with the burgeoning taste for the lowlife picaresque in Europe, one of the most important developments in late sixteenth-century literature. ${ }^{10}$ This form of fictional autobiography flourished first in Spain and then in many European literatures through the seventeenth and eighteenth centuries (Beeching 2000, 20); told from a first-person perspective, the picaresque relates a series of adventures of a usually lower-class, uneducated protagonist who is witty and sly enough to move up the social ladder. The travels and adventures-some of them voluntary, some involuntary-are told in a series of episodes and find 
an ending in the reintegration of the picaro into the social order. J. S. Bromley emphasizes that the resemblances between the picaro and the pirate in their libertinism were a result of the fact that both these outcasts, lowly social misfits, had nothing to lose: "willing to lose everything on the throw of a dice, then begin all over again ... . Living from day to day, at the mercy of events, the picaresque rogue is seldom his own master for long, yet living on his wits he can assert his independence and turn the table on masters no more virtuous than himself" (9-10, quoted in Latimer 2009, 76).

For these reasons, piracy narratives share many of the characteristics of the picaresque (homodiegetic first-person narration, travel and adventure, episodic structure, transgression of social and legal norms), but attribute much more space to the narrative articulation of cultural contact, nature observation, and technical information (navigation, climate, etc.) as they are fundamentally fragmented in terms of generic form. The fact that Daniel Defoe, one of the main authors to translate the genre into English fiction in the early 1700s, turned to earlier narratives of piracy for many of his adventure books, indicates that seventeenth-century transatlantic piratical narratives are important forerunners of the Anglophone picaresque.

A contrapuntal reading of late seventeenth-century accounts of piratical ventures hence needs to take heed of the fact that the imperial subjects represented by these authors and narrators were themselves fragmented and fluid, border crossers on the margins of an empire in the making. In the process of discursively solidifying these new colonial subjectivities, these publications strive to create indigenous voices as pro-English, while African-Americans emerge, if at all, as mere traces of colonial violence. The texts themselves invite a contrapuntal reading, as their narrative voices are full of doubt and mistrust in their American environments (both natural and cultural), unsteady in their alliances (e.g., with indigenous and creolized Spanish populations; with the English imperial design and a proto-Creole alternative), ${ }^{11}$ and thus often hard to grasp. In Peter Hulme's phrasing, these are instances where "the text stutters in its articulation" and offers "levers to open out the ideology of colonial discourse, to spread it out, in this text, in an act of explication. ... [N]o smooth history emerges, but rather a series of fragments which, read speculatively, hint at a story that can never be fully recovered" $(1986,12)$. Counterdiscourses disappear behind chorographic description and re-emerge as disturbances to a linear patriotic narration. I propose to characterize the 
multiplicity of these voices as piratical and coastal in order to emphasize their transgressiveness, instability and fluidity, but also their criticality in terms of legitimate authorship and coloniality.

In the following, I compare Exquemelin's 1678 Zee-Roovers, the earliest model of such piratical chorographies, with those of his English successors in order to highlight the shift taking place before the turn to the eighteenth century, as piracy was appropriated in writing and instrumentalized for a scientific imperialism in the context of a symbolic and factual empire-building that rested on gaining the authority of knowledge over the Americas. ${ }^{12}$ As Sarah Irving has argued in the context of the epistemological shift from allegorical, pre-modern, to taxonomic, modern science (proclaimed by Michel Foucault), "America was conceptually significant, as it gave shape to a tradition of empire as dominion over knowledge" $(2007,28) .{ }^{13}$ Similarly, Payton records a shift from "the enchanted worldview of romance to the disenchanted worldview of scientific modernity" $(2013,240)$ in his discussion of Exquemelin. Yet despite the efforts by Ringrose, Wafer, and most notably Wafer's friend William Dampier ("the best know sailor-narrator of the seventeenth century" [Munter and Grose 1986, 423] who became a member of the Royal Society due to the publication of his travel narrative) to legitimize the (semi- or illegal) piratical expedition by framing their narratives as science books, their texts also demonstrate the problematic of authority in this imperial endeavor. From a contrapuntal perspective, these narratives thus both hide and reveal the discomfort and fragility of colonial (symbolical and political) economies as "the material and discursive construction of imperialism becomes its own critique and the process of its development becomes its own overturning" (Payton 2013, 342 in reference to Hardt and Negri).

\subsubsection{The Caribbean Buccaneer-Pirate as an Embodiment of Crisis}

The term buccaneer, though it became conflated with pirate in the seventeenth century-also via popular accounts of piracy among the buccaneers since the 1640s-referred to Caribbean hunting communities that resisted subjugation by the French crown. Originally French Huguenots (a presence in the West Indies since the 1520s) and later joined by remnants of Oliver Cromwell's New Model Army and other radical Protestants of various European nations (Hill 1984, 20; Latimer $2009,11)$, the buccaneers can be viewed as showing an early form of 
creole consciousness; Exquemelin reports that they "strongly resented the attempt to bring them under subjection, in a land which belonged neither to the King nor the [French West India] Company, and resolved not to work rather than be dominated" ([1678] 1969, 62). In addition, the buccaneers were often welcomed and supported by colonist groups against official policies, as they often supplied them with cheap slaves and commodities (Latimer 2009, 235; English and French smugglers had even sold firearms to the Caribs, which they used in their fights against the Spanish colonizers, 62). Buccaneer leaders' names like the Dutchborn "Rock the Brazilian" (Exquemelin [1678] 1969, 80-82) are also indicative of creole rather than imperial identification.

The name for these "masterless men" (Rediker 2004, 286), sailors and indentured servants, unemployed workers and artisans, who took refuge as hunters in the forests of Hispaniola, Tortuga, and other fringe zones of the colonial empires, points to the cultural and linguistic hybridity of this group specifically and to the Caribbean contact zone in particular, placing the buccaneer on a continuum with the "Indian" and the Maroon/cimarron (runaway slave): "boucan" has been traced etymologically to the Taíno Arawak word for the place and wooden grating used to smoke-dry meat, a method the European refugees had learnt from these natives (who, by the late seventeenth century, had mostly died through diseases or been enslaved) and shared as a practice with the maroons (see Bev Carey's “Jerk Pork Connection," 1997, 66; De Lourdes Edwards 2007, 627; other sources call it a Carib word, e.g., Beeching 2000,9 ). Buccaneer communities had their own code of social conduct and organization (the "custom of the coast" / Fr. "coutume de la côte," later also called "Jamaica discipline" in reference to the Jamaican pirates; Latimer 2009, 239), including the homosocial bonds of matelotage. ${ }^{14}$ They turned into pirates and mercenaries when the Spaniards, seeking to dissolve these outlaw communes, destroyed the wild herds of cattle on which their hunting society subsisted. Although the buccaneers were eventually eliminated by the English when they had made peace with Spain, both English and French agents in the Caribbean made frequent use of these men's excellent marksmanship and raiding skills in their wars against the Spanish trade monopoly. Thus, they were both resistant to and complicit in the colonial wars between the three major European empires, which instrumentalized yet never fully controlled their Caribbean "task force." 15 Rennie calls them "Europeans who had become 
American savages [sic] ... colonists in reverse, colonized by savagery, tribalized and culturally reinvented" similar to the later frontiersman (2013, 16).

As pirates, the buccaneers were defined ex negativo by their lack of any official, national backing. Their implicit political heterogeneity and indefinability represented a general threat to political categorization and order-the buccaneers have been described as unfathomable, unreliable, uncivilized, 'barbarous' and cruel, even monstrous, in contemporaneous accounts such as Exquemelin's, prone to gluttony and squander, defiant to industry and labor: a threat to the translatio imperii particularly in times of peace, when they could no longer be contained legitimately as privateers within the imperial project and endangered international colonial agreements: "Where previously a weak or tolerant state had tolerated smugglers," for instance, "now their resistance made them pirates" (Pérotin-Dumon 1991, 199). Economically, they stood for the opposite of the accumulative ethics that marked mercantilism and proto-capitalism, defying labor, frugality, and rational economic behavior-instead, the buccaneer-pirate was idle and profligate, an almost Bataillean figure of excess. As a figuration of alterity, he thus ranks in close relationship with the 'cannibal,' the 'savage,' and a number of outlawed subjectivities who tried to retain agency in the colonial theatre such as the maroon (but in opposition to the slave, who is defined by a denial of subjectivity and agency). In the foreword to his 1926 German translation of Exquemelin's Zee-Roovers, for example, Hans Kauders describes the buccaneers as "men of prey" (originally "Raubmenschen," my translation), drawing on the distinction between the raw and the cooked as a mark of civilization explored by anthropologist Claude Lévi-Straus four decades later: they "plunged upon the culled bull and sucked the marrow, still warm from his bones, ... devoured the meat, their only food, even raw if necessary, $\ldots$ [and] tortured their human victims most cruelly" $(1926,13) .{ }^{16}$

Yet even the representation of "monstrous pirates" in Exquemelin (or in Puritan anti-piracy sermons, for that matter) cannot hide that this alterity offered a way of life beyond official control, which for many was the only alternative to indenture, enslavement, and lethal exploitation. Captain John Smith explained the attractiveness of piracy for the English also in political-economic terms, writing that "King James who from his infancie had reigned in peace ... had no imployment for those men of warre so that those that ... were poore and had nothing but from hand to mouth, turned Pirats" (quoted in Latimer 2009, 30). Others had been left 
out of work and in debt in the course of the transformation of the plantation system into a slave economy (95); the phenomenon of Caribbean piracy and buccaneering can be understood as a symptomatic consequence of unemployment and of the uncontrollability of colonialists who developed an agency of their own. The moment of 'turning pirate' meant that sailors appropriated a mobility they had so far known only as a result of (usually economically motivated) coercion.

Out of a mass of sailors, plantation workers, indentured servants, and to some extent even slaves, all of whom became part and parcel for the stabilization of a fledgling Atlantic economy of accumulation in the seventeenth century (geared toward profit for its European centers), an Atlantic proto-proletariat was formed, as Peter Linebaugh and Marcus Rediker argue, formulating the concept of a "Red Atlantic" of expropriation and capitalism, proletarization and resistance-parallel to Paul Gilroy's Black Atlantic (Armitage 2001, 479; Linebaugh and Rediker 2000, 61). This early modern working class, essential as it was for the economic development of both land and sea, seems to have been informed by word of mouth about the fact that pirates organized themselves according to proto-democratic principles (one man, one vote), that they offered social security to some extent (such as injury compensation and pensions), ${ }^{17}$ that their only master was the crew and its chosen captain, and that this life promised more freedom, if not less hardship. The fact of communal solidarity, sharing, deliberation, and consensual problem-solving is often emphasized in the contemporary literature of piracy: the buccaneers are "extremely loyal" (Exquemelin [1678] 1969, 72); they "resolve by common vote where they shall cruise" (71); "the men decide whether the captain should keep [a captured ship] or not"; and they "helped one another all they could, those who had money sharing with those who had none" (232; see also Ringrose 1685, 150, 159, 162; Dampier 1697, 12: "none should live better than others, or pay dearer for any thing that it was worth").

Harking back to Christopher Hill's classic essay "Radical Pirates?" (1984) and Eric Hobsbawm's theorizations of Primitive Rebels (1959) and Bandits (1969), Linebaugh and Rediker's interpretation seems somewhat overdrawn if read against the texts under discussion in this chapter. While the narratives by Exquemelin, Ringrose, Dampier, and Wafer all mention collaboration with autochthonous peoples and the presence of Africans, they also make clear that members of these groups were hardly 
equal participants in the buccaneer-pirate communities. Quite to the contrary, both the buccaneers and their enemies used these groups as slaves, servants, and military personnel. ${ }^{18}$ A passage from the third part of Exquemelin's Buccaneers sets forth the ambivalent terms on which their ventures are based-the exploitation of women, African-Americans, and indigenous subjects:

The rovers are on such friendly terms with the native people they can stay and live among them without risk of harm, and without a care in the world. The Indians give them all they need, in exchange for which they give the Indians nothing but old knives, axes and tools ... . When a rover comes there, he buys a woman from the Indians for an old axe or knife, and for this fee she must stay with him till he leaves ... . A man who has taken an Indian wife has nothing to worry about: she brings him his daily food, as is customary among the Indians. The man need do nothing but a little hunting or fishing. A white man need not even do this, but may order an Indian to do it for him. ... These Indians are a great asset to the rovers, as they are very good harpoonists [and] extremely skilful. ... In fact, an Indian is capable of keeping a whole ship's company of 100 men supplied with food. ... ([1678] 1969, 219-20)

The buccaneer-pirate crew is located in a colonial land of Cockaigne structured by an economy of color in Exquemelin's terms, as the "Indians" are constructed as stationary and at the service of the mobile rovers, and autochthonous women are sold for a fee, an act that virtually enslaves and immobilizes them as long as their (white) masters wish. At the same time, the relations between the buccaneers and "Indians" are described as harmonious; the text here does not paint the natives as cannibalistic, savage enemies, but as welcoming the buccaneers and as being happy to serve and labor for them. The superiority of whites-however "motley" their crews-is clearly upheld by such passages. Yet if, according to Hanna, many reports of "black or multiracial crews were fabricated" and related to fears of slave revolts rather than actual black pirates (2015, 384; see also my reading of Melville's "Benito Cereno"), this conception of pirates as "motley" testifies to their radical potential as subjects of resistance.

Pirates and buccaneers knew captivity and robbery, disenfranchisement, rape, and enslavement more often as agents than as victims. Quoting W. Jeffrey Bolster's seminal monograph about African-American seamen, 
[b]uccaneering tempted black seamen with visions of invincibility, with dreams of easy money and the idleness such freedom promised, and with the promise of a life unfettered by the racial and social ideology central to the plantation system. Unattached black men operating in the virtually allmale world of the 'brotherhood of the Coast' realized those yearnings to a degree, but also found abuse and exploitation, as well as mortal combat and pursuit. $(1997,13)$

To romanticize the buccaneer-pirate communities as either formations of resistance against or as complicit with an eventually benevolent, liberatory colonial project is thus a gross simplification; as liminal figures they did not find themselves beyond dominant relations and discourses, especially with regard to race and gender. In addition, the very fact that a wide range of piratical texts entailed proto-ethnographic, geographic, and nautical descriptions is evidence of the close relationship between the pirate and the explorer, who, in the case of William Dampier, was actually one and the same. Scholarship of Caribbean piracy, then, has to "resist the reduction of cross-cultural encounter to simple relations of domination and subordination" and "must acknowledge not only its complicity, but also its power of re-figuration and aspiration towards a more benign ethics of alterity" (Clark 1999, 3-4). The pirate at the end of the seventeenth century oscillates between a figure of alterity, defined by aberration from legal, social, religious, and cultural norms, and a figure of identification, who produced a fantastic imaginarium in which the armchair colonialists "whose lives have never taken them far from their mother's kitchen" (Exquemelin [1678] 1969, 188) back in Europe could imagine the New World as a place of abundance, liberty, and adventure; the designation of a new world itself suggested limitless possibilities for European economic, political, religious, and social renewal (Frohock 2004, 21).

In sum, the pirate-buccaneers can be understood as an embodiment of political, economic, and cultural-epistemological crisis. Pirates mark the erratic return of the repressed in the burgeoning colonial order due to the unpredictability of their actions and alliances; the defiance of an accumulative economy; and the threat they posed to categories of cultural categorization in the context of their 'going-savage' and their 'going-native,' collaborating with autochthonous groups and appropriating indigenous ways of life. 


\subsubsection{Exquemelin's Zee-Roovers/Buccaneers of America}

The first book-length narrative to afford its readers "an inside look at Caribbean buccaneers" (Arnold 2007, 10) was De Americaensche ZeeRoovers of 1678 by Alexander Olivier Exquemelin, originally published in Dutch and in the course of only a few years (rather loosely) translated into German (Nuremberg 1679), Spanish (1681), English (1684), and French (1686) in numerous editions, ${ }^{19}$ which made it a transnational best-seller by seventeenth-century measures. The book presented European readers, often of "the wealthy Calvinist merchant class" (Arnold 2007, 13) with "a novel and shockingly candid portrait" (Frohock 2010b, 56) of the buccaneers, catering to the contemporary taste for the sensational and the spectacular, which was tightly intertwined with the imperial project of discovery, as Stephen Greenblatt has argued for the Renaissance context in Marvellous Possessions. The book became a standard source for subsequent piracy literature and fiction (e.g., by Captain Charles Johnson and Daniel Defoe). Published under the name of a (probably French) indentured laborer who became barber-surgeon for pirate captains François L'Olonnais and Henry Morgan, ${ }^{20}$ its author was actually not sufficiently fluent in Dutch to have written the book by himself (Beeching 2000, 19); it was most likely his Amsterdam publisher, Jan ten Hoorn, who brought Exquemelin's oral account (or perhaps French manuscript) into the form in which it was eventually published (Ouellet 2004, 53).

In the text, which is persistently marked by its collective authorship, by traces of orality, the process of translation, and linguistic, narrative, and formal hybridity, ${ }^{21}$ the implied author-narrator recounts his service in the French West India Company in Tortuga until the company's expedition is dissolved for bankruptcy and he is sold to a cruel master. Sick and on the verge of dying, he is bought by a philanthropic surgeon who lends him the money to buy back his freedom after his recovery. Wanting to return the money he owes and lacking other means of its acquisition, Exquemelin enlists with the buccaneers for five years before returning to Europe (he would return to the Caribbean in 1697, participating in the attack on one of the most important Spanish ports, Cartagena de Indias, in present-day Colombia).

Exquemelin's book is the most genuinely transnational, compared to Ringrose's, Wafer's, or Dampier's (whose cultural function can only be understood in the context of British empire-building); in her influential essay "Traveling Genres," Margaret Cohen cites the Buccaneers as a prime 
example of sea voyage narratives "whose national location is often hard to pinpoint due to the itinerant quality of their authors and publication histories" (481). Traditional concepts of authorship, of Dutch (or French) literature, of original and translation are difficult to apply here:

... on revient ... à une période antérieure où la notion d'auteur original avait beaucoup moins d'importance ... . Quant aux éditeurs, ils ne nient pas la réalité de l'auteur: ils s'en servent plutôt pour cautionner la véracité du livre qu'ils publient. Lors même qu'ils utilisent le texte de l'auteur comme un simple canevas, ils affirment avec emphase sa qualité de témoin pour donner de la crédibilité à une entreprise littéraire fort éloignée, thématiquement et idéologiquement, de ce qu'on imagine être l'original. (Ouellet 2004, 36) ${ }^{22}$

Falling between the cracks of any national literary historiography, Exquemelin's text has received little scholarly attention so far-despite the fact that transatlantic and transnational studies are by now a wellestablished perspective in literary and cultural studies. ${ }^{23}$ It presents a rare testimony of the Red Atlantic, written from the perspective of an indentured servant who underwent severe hardship under the command of various abusive masters-both outside and inside the buccaneer communities. As literature from below in terms of class and from between in terms of national tradition, it exposes colonial labor relations and systematic abuse that official histories glossed over for good reason:

[o]fficial histories provide no platform for exposing [colonial] abuses; the point of critique can come only from the perspective of the humble, solitary eye-witness, who has intimate knowledge, but also a moral distance, and who consequently can see that the horror of piracy, which consists of atrocities concealed and advanced through discursive manipulation, is also the horror of imperialism generally. (Frohock 2010b, 68-69)

All this happens under the pretense that the book is merely a description of horrific sea-rovers, when in fact it uses 'the horror of piracy' as pars pro toto for 'the horror of imperialism.'

The first seven chapters recount the author-narrator's travels to Tortuga and Hispaniola, accompanied by a detailed description of the islands' nature as marvelous and Edenic (spurred perhaps by his medical interest in plants, de Lourdes Edwards 2007, 626), explanations of the 
political relations between various European colonizing agents, the plantation economy and its harsh treatment of indentured servants and slaves, and an in-depth account of the buccaneers. Exquemelin's plea for better treatment of indentured servants by plantation owners of all nationalities articulates an Atlantic proto-proletarian consciousness across national borders that is quite stunning for the time:

[The planters] trade in human beings just like the Turks, selling bondsmen among themselves as people in Europe deal horses. ... They make big promises [recruiting them among European peasants], but when the lads get to the island they are sold and have to work like horses, harder in fact than the Negroes. For the planters admit they must take greater care of a Negro slave than a white bondsman, because the Negro is in their service for life, while the white man is theirs only for a period. They treat their bond-servants as cruelly as the [buccaneer] hunters do, showing them no pity at all. ([1678] 1969, 64)

The narrator goes on to describe the harsh working conditions, the bad diet, various illnesses (bodily and psychological) among them, and brutal torture such as smearing their wounds with lemon juice, salt, and red pepper after a beating. "They are forced to work with blows, often until they drop down dead. Then the planters complain, 'The rascal would rather die than work.' I have often seen such cases, to my great sorrow" (64). Exquemelin also relates various examples of their attempts at resistance: of indentured young men who run away and starve to death, who kill their master and are hanged. He differentiates between various national practices on the Caribbean islands, but emphasizes that "[a]trocious cruelties" are common to the plantations regardless of the nationality of their owners. His charges mention tyrants like the planter Belteste on St. Kitts (65), who "dared to say it made no difference to him whether he should be damned or saved, so long as he could leave enough wealth behind him for his children" (66) or English planters who "treat their servants no better, but with greater cunning," continuously lengthening the period of indenture so that many men "have been enslaved in this manner for fifteen, twenty and twenty-eight years" and following "a strict law that when anyone owes the sum of twenty-five shillings ... he may be sold as a slave for a certain period."

The subtitle promises "a pertinent and truthful description of the principal acts of depredation and inhuman cruelty committed by the English 
and French buccaneers against the Spaniards in America," countering the myth of the leyenda negra as it locates inhuman cruelty among English and French Protestants as well; in his report of buccaneer society, Exquemelin describes them as the worst masters of slaves and indentured servants, for example, "cruel and merciless to their bondsmen: there is more comfort in three years on a galley than one in the service of a boucanier" (55). Yet the book does not take sides with Spain either; "depredation and inhuman cruelty" are committed by all kinds of Caribbean agents in the book. The buccaneers themselves are represented as far from an egalitarian alternative for the Caribbean subalterns; the figure of the buccaneer is coastal in Exquemelin not just in terms of his localization on Caribbean (as well as Pacific) coasts, but also with regard to cultural contact, as the narration devises a colonial continuum between 'savage' autochthonous populations, Spanish colonizers, and Protestant newcomers through the representation of violence in all of these. The pirates are located somewhere between these identities. The buccaneers, Richard Frohock explains, "are not an anomaly in the colonial experience but rather an exemplar of the violence and exploitation perpetrated by imperialist centers" $(2010 \mathrm{~b}, 66)$. Exquemelin's text relativizes the construction of the pirate as Other, contesting the dominant construction of a binary opposition between legitimate and illegitimate Caribbean agents.

Numerous illustrative engravings (possibly by Jan Luykens, Arnold 2007, 13) emphasize this intermedially (e.g., Fig. 2.1): killings, subjugation, and methods of torture used by the buccaneers are described and depicted in gory and excessive detail (Exquemelin [1678] 1969, e.g., 11, 39, 106; also Payton 2013, 339), reminiscent of contemporary horror films, but are not limited to any one of these groups. To the contrary: the narrator authenticates his descriptions of torture methods, for instance, by naming an "Indian who had often treated his enemies in this manner, and it has also been seen by Christians living among these tribes" (39). The littoral space of the Caribbean itself, as the center of colonial struggles in the seventeenth century, rather than any specific group there, is constructed as violent.

The etchings articulate another paradoxical colonial continuum, representing the buccaneers both as 'uncivilized' brutes and as European gentlemen-emigrants who have successfully claimed agency in the Americas, despite their often gruesome deaths (which are represented in a manner of poetical justice). 


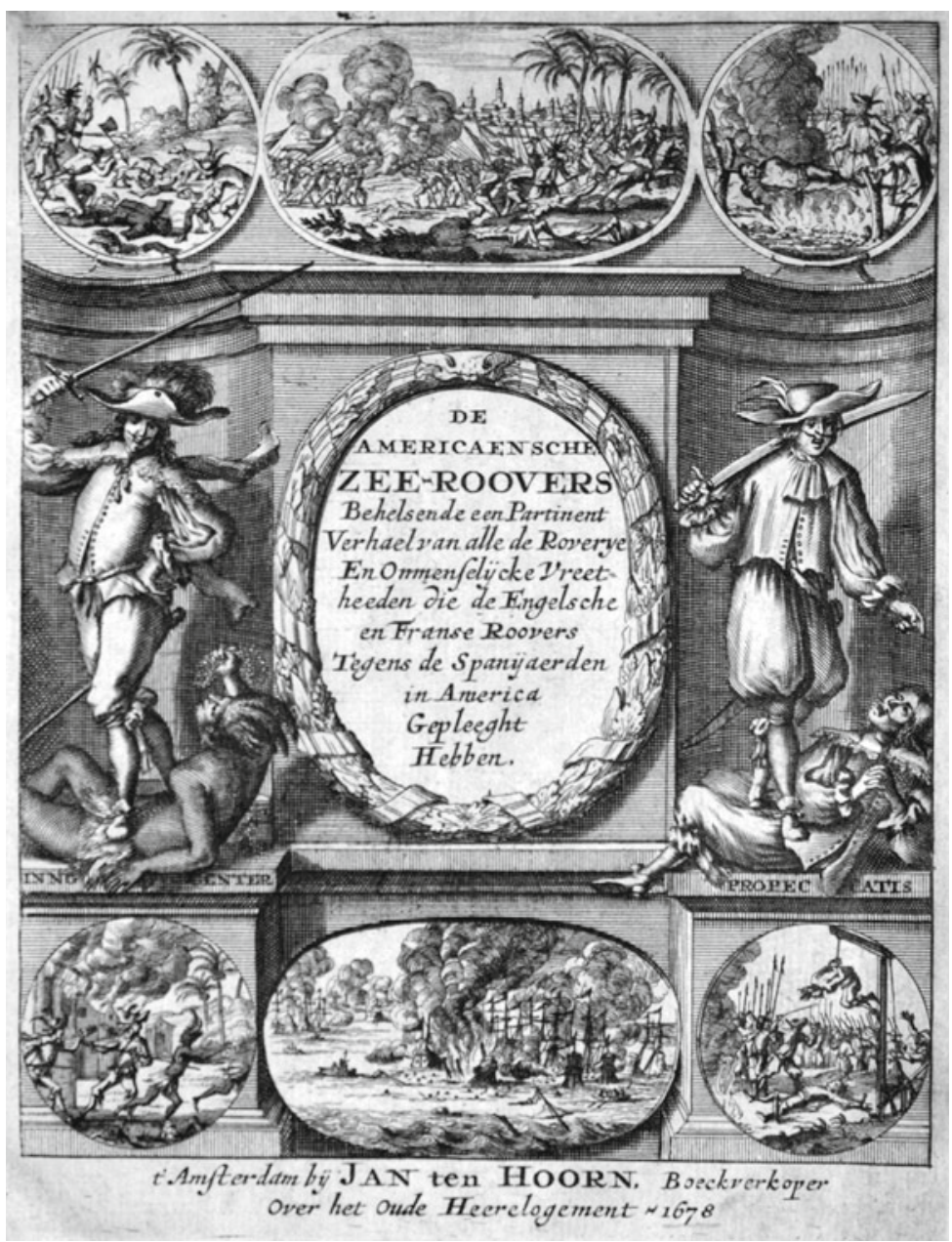

Fig. 2.1 Engraving in Exquemelin's Buccaneers of America, used in both the Dutch original and the English translations (Courtesy of Library of Congress)

The portrait gallery of the most notorious buccaneers indeed turns them into heroic "gentlemen of fortune," as they often insist to be called in Exquemelin's book. In this way, the text negotiates social mobility, highlighting the coastality of class difference: reaching the Caribbean 
coast entails the opening-up of a rigid European social system governed by both class inheritance and the beginning of the myth of American freedom and a classless society. In contrast to the legitimate colonizer, the pirate's ascent seems to be predicated on exploitation and criminal transgression, but Exquemelin's colonial continuum disturbs this binary vision.

The violent continuum is extended beyond the Caribbean coast toward the Pacific via Panama but also reaches back to Europe. Emphasizing violence, deviance, and difference in the West Indies in terms of both nature and cultures, Exquemelin presents an exotic, transgressive, and spectacular Caribbean Other and a space of marvel and awe to the metropolitan reader (a hermeneutic strategy that primarily creates satisfaction among colonial audiences that expect this topos of the ethnographic narrative, Hartog 1988, 230-37). But because he has to bridge the hermeneutic gap of the Atlantic, the text relies on comparisons, analogies, and similes, yet another of the major hermeneutic strategies to render the 'exotic' and the unknown believable and comprehensible (225-30). With Europe as a reference point, for instance, Exquemelin compares "the coming of the hunters and the privateers" to Caribbean coastal towns with that of "the East India ships and men-of-war" to Amsterdam ([1678] 1969, 54), which are both accompanied by wild feasts and wastefulness; more frequently, foreign plants and animals are set into relation with European flora and fauna. As ordering and structuring instruments, these similes aim at pacifying the colonial chaos of the Caribbean, but read contrapuntally, they construct the dark side of coloniality as not beyond, but at the very heart of Europe: without the absent center in constant reference, America cannot 'mean' anything. Taking into account these ambiguities of narrative identification and distancing, the piratebuccaneers are hard to pin down conceptually; they appear as mobile subjects in a colonial continuum of economic exploitation, violent practices of oppression, and resistance, a continuum that begins in Europe and stretches across and beyond the Atlantic. They are neither mere outlaw disturbers of imperial maritime undertakings, nor, conversely, straightforward supporters of these ventures. Exquemelin articulates, with the figure of the buccaneer at the center, a culturally hybrid population on the fringes of metropolitan control and comprehension.

The subtitle also indicates an authorial attempt of dissociation from the pirates, necessary first in order not to endanger Exquemelin's legal position as their servant rather than fellow buccaneer, and second not 
to undermine his authority by associating him with these outlaws. The tension between familiarity and distance is pertinent throughout the book; as Richard Frohock has argued, Exquemelin "must show himself to have been close enough to have observed events firsthand, but sufficiently removed that the disrepute of piracy does not tarnish his character" $(2010 \mathrm{~b}, 57)$. This is apparent already on the title page, billing the narrative as written by one "who himself, of necessity, was present at all these acts of plunder" (my emphasis).

Narrative dissociation works on another level as well: although the Spaniards are made responsible by the book for the mistreatment and destruction of the indigenous populations, in accordance with the leyenda negra, the narrator does not side with any national-colonial project as his voice remains at a distance from any sort of national loyalty as well as from the buccaneers themselves (see also Payton 2013, 340). Only when Exquemelin thematizes his personal history autobiographically, authorial distance is briefly interrupted; these sections establish a firm narrative "I": "As a servant of the [French West India] Company myself, I was among those sold, and had just the ill luck to fall into the hands of the wickedest rogue in the whole island" ([1678] 1969, 34; the "wickedest rogue" here does not refer to a slave-holding buccaneer master, but Tortuga's deputy governor). When he is resold to his savior, he recounts: "When I was free once more, I was like Adam when he was first created. I had nothing at all, and therefore resolved to join the privateers or buccaneers." Evoking biblical innocence also in terms of knowing-Adam when he was first created instead of Adam after having eaten from the tree of knowledge-in this representation of his agency's rebirth, the narrator implies that freedom also means the necessity to take care of one's subsistence. Legitimizing the buccaneers by calling them "privateers" here, the narrator strives to present himself as indigent and socially detached, an outsider rather than a voluntary associate (Frohock 2010b, 58). This disassociation is also strengthened at the beginning of chapter six, when he refers back to how he "was driven to join the pirates"-now using the term to delegitimize them as he does not "know what other name they deserve, as they were not backed by any prince" (Exquemelin [1678] $1969,67)$. It is significant that the various denominations-buccaneer, privateer, pirate - are often used interchangeably in the book, demonstrating the narrator's great ambiguity in terms of the(ir) linguistic and legal categorization-his coastal vision of the pirate as a figure suspends clear categorization. His cautiously careful dis-identification of course also 
owes to his own ambiguous legal position as (quasi-indentured) servant of the buccaneers-he refers to "my own master" among them, for instance $(82)$-while being treated with respect for his skills as barbersurgeon. ${ }^{24}$ Yet a third aspect is the preservation of narrative authority by distancing himself from the pirates. The narrative voice remains liminal, at the crossroads of identification, as familiar categories seem out of joint.

The establishment of narrative authority and authenticity is indeed crucial in Exquemelin's and similar chorographical-piratical texts. One of the major questions about the genre of the seventeenth-century pirate narrative thus relates to the strategies necessary to lend authority and credibility to sensational stories about pirate-buccaneers. As Richard Frohock argues, the historian's interest in Exquemelin and the question of truth versus fiction is less fruitful than considering how Exquemelin "continually engages with issues concerning language and authority," as he "was fascinated with the challenges of producing credible accounts of experience and with the techniques and politics of manipulating narrative for empowerment" $(2010 b, 56)$. The nature of crisis in Exquemelin, as I argue, is one of authority and the word, a crisis of narrative form and of identification with the coloniality of power in terms of its dichotomous categories of rational and irrational, civilized and savage, good and bad.

Frohock has identified mainly two narrative modes in Exquemelin: the first-person authorial voice that is presented as credible and independent, and the critical dialogic voices inserted through the frequent use of reported speech, including that of the "linguistic rebel[]" (2010b, 57) of the buccaneer. Arguably, there is a third mode that helps him not to undermine this delicately constructed authority (e.g., by being identified as a criminal pirate), that is when the narrator completely obliterates his own voice (Exquemelin [1678] 1969, 58); becoming heterodiegetic, he thus hides behind factual observation (but reappears whenever further authorization is needed). Consequently, the relationship between narrator and narrative becomes fraught and unclear-especially when cruelty and excess, sumptuousness and wasteful squandering are reported and Exquemelin veils his own role in the events. Here the buccaneers are clearly "they":

They squander in a month all the money which has taken them a year ... to earn. They drink brandy like water, and will buy a whole cask of wine, broach it, and drink until there's not a drop left. Day and night they roam 
the town, keeping the feast of Bacchus so long as they can get drink for money. The service of Venus is not forgotten, either. (54)

For that is the way with these buccaneers-whenever they have got hold of something, they don't keep it for long. They are busy dicing, whoring and drinking so long as they have anything to spend. Some of them will get through a good two or three thousand pieces of eight in a day-and next day not have a shirt to their back ... . Yes, and many other impieties. $(81-82)$

Women, again, are the providers of service, while men are mobile, consuming subjects, roaming the towns; other providers of military and labor service, unsurprisingly, are "Negroes" and "Indians" (as they are termed throughout the book). The narrator, although to some degree part of the piratical crew himself, obliterates his presence and role in these events completely (rather than addressing a moral dilemma as witness of these scenes or as immoral participant), creating the impression of passive and objective observation, concomitant with the seventeenthcentury "invention" of the concepts of truth, objectivity, and rationality (Shapiro 1983). The use of the first-person narrative "I," although it creates involvement and presence rather than distance, can also be read as a strategy of individual dissociation from the collective "buccaneers." Nevertheless, on 38 of about 200 pages, the first-person plural narrative "we" appears mostly vis-à-vis autochthonous groups (Exquemelin [1678] 1969, e.g., 211) or regarding collective decision-making processes; occasionally, Exquemelin also uses an authorial plural developing into a "we" that includes the reader ("Having ... described these ceremonies of the sailors, we will now continue our journey," 27; "While our rovers are engaged in this work, I will briefly describe," 115), thus constructing a colonial collective that includes the European armchair adventurer. The entire narrative appears extremely fragmented by the frequent changes in narrative mode, leaving much space for the reader's imagination, but also creating disorder and chaos in the reader's mind-despite all efforts in the construction of narrative authority. ${ }^{25}$

Exquemelin needs help in this narrative construction work: as the narrator repeatedly emphasizes, he derives his authority first from a discourse of witnessing and testimonial. Second, he emphasizes knowledge of informants of various cultural backgrounds and their trust in 
him: "trustworthy persons" (45) like the above-mentioned "Indian" whom he lends his voice-not in order to render subaltern voices audible for his European readers, but for his own advantage, catering to the enhancement of his credibility and reputation as an informant. In a contrapuntal reading, however, the fact that he uses "savages" as voices of authority also shows the dependence of metropolitan publications and their credibility on the native informant.

In contrast to Dampier's, Ringrose's, and Wafer's narrators, Exquemelin's voice is much more insecure and frail, certainly also because he is exiled from official colonialism through the experience of indenture, the economic failure of the colonial endeavor, and a lack of opportunity for re-integration into any national 'home' society. ${ }^{26}$ The coastal subject of the contact zone is unable to discursively control chaotic colonial identities-in-transculturation, buccaneers as well as "Indians" and Spaniards, swerving between admiration and indignation, collaboration and resistance. In the case of the pirates, their portrayal ranges from respect for their fraternity and mutual loyalty to contempt of their way of life and sheer horror of their "barbarous" (200) ways, for example when he reports that they almost exclusively live on meat, "even eat apes" (106), literally lick the blood of their enemies (106) and in times of starvation "determined to eat the Indians" (118) and "had been found picking the corpses of the fallen Spaniards" (206). ${ }^{27}$ In this way, Exquemelin's book demonstrates that the Caribbean, as a space of all kinds of imperial and colonial struggles, turns everyone into "savages"even "cannibals"-effectively de-ethnicizing and de-essentializing these terms, central to colonial epistemology.

This paradoxical attitude is perhaps most explicit in Exquemelin's report of Henry Morgan and his raid on Panama, in the second part of The Buccaneers of America. The narrator is fascinated by Morgan's popularity and his leadership skills, which, despite his cruelty, earned him the solidarity of up to a thousand buccaneers, plundering the Spanish riches in his command. The episode starts with an avowal of belief in the glorious fate of the Protestants in their battle against the Spanish Catholics: in a providentialist vein typical of all of the texts under consideration in this chapter, the "curious reader shall see how God permitted the unrighteousness of the buccaneers to flourish, for the chastisement of the Spaniards" (167): the legitimacy of the buccaneer-pirates, however monstrous, is that they are needed to combat enemies of equal monstrosity, in reference to the leyenda negra; "God allows the cruelty 
of the buccaneers in order to exact vengeance on the Spaniards for their deplorable history of cruelties in the Americas" (Frohock 2010b, 66). The violence and success of the monstrous buccaneers is expressive of a higher power, which not only explains Morgan's ruthlessness, but is presented as necessary in order to save the New World for Protestantism and England (Arnold 2007, 12). ${ }^{28}$ Ironically, this providentialism constitutes an English reproduction of Spanish colonial discourse, which also fashioned itself as God's plan (Frohock 2004, 33).

After reports of great starvation among the troops and Spanish and indigenous resistance (Exquemelin [1678] 1969, 189-92), the text continues to describe Morgan's methods of torture in detail. The women of Panama City are not spared, though they are depicted as susceptible to the gallantry of the buccaneers. Again, the narrator distances himself from the violence of the pirates and reports that he secretly helps the Spanish victims of the buccaneers. Eventually, he appears similar to the Spanish women themselves, who had been warned that they would not be able to bear the sight of the "buccaneers' deformity" (202) since they were more like animals than Spaniards (metonymically used for humans); when they first encounter the pirates, however, they shout, according to Exquemelin: "Jesus, the robbers are just like us Spaniards, ... as courteous as if they were Spanish!" Again, a colonial continuum (rather than an opposition) of behaviors is affirmed-here, the difference between 'bad' Catholic Spaniards and 'good' Protestants, between buccaneer savagery and humanity is held in suspension by the dissonant, contrapuntal voices of female colonists, which no official history would record. This polyphony likens the women of the town to the narrator: they both appear indecisive in their view of the pirates, expressing both disgust and admiration.

Morgan, who had risen from an indentured servant to a plantocrat partly backed by the Jamaican governor Modyford, felt misrepresented. As he was trying to rehabilitate himself and make a political career (he had become a nobleman and vice-governor of Jamaica in 1674 and had turned against the buccaneer-pirates, now fearing for his position when the Catholic King James II succeeded to the throne), he sued the two English publishers that had sold "Esquemeling's" book in two different translations in a premiere in the history of English law, since it was the first case of libel: "He was not a pirate, he said; he was a privateer, and therefore respectable. He ... insisted that there are such thieves and pirates called buccaneers who subsist by piracy, depredations and evil 
deeds of all kinds without lawful authority, that of these people Henry Morgan always had and still has hatred'" (Latimer 2009, 256; also Arnold 2007). Morgan won and received compensation money, and the publisher Crooke subsequently issued an apology for the association of Morgan with piracy. ${ }^{29}$

In sum, by alternately stressing similarity and difference between the Caribbean and Europe, Exquemelin's text is testimony to a transatlantic population-in-transculturation on the fringes of metropolitan control, inhabiting, in the words of Eric Wolf, "the margins of constituted society and liv[ing] off the flotsam and jetsam of its resources" (1982, 154-55). These multiethnic populations, a "great mingling of races" according to Exquemelin ([1678] 1969, 36)-Europeans, autochthones, cimarrones, and slaves - are met with both sympathy (even identification) and distance, rendering the narrative heterogeneous and full of inner tension, emblematic of a crisis in epistemology, a crisis of knowing and telling that accompanied the colonial project in the Americas.

\subsubsection{Attempts at Consolidation: Pirate-Scientists' Texts}

Exquemelin's chorographic adventure book achieves no narrative closure, but "the acceleration of a public dialogue about buccaneers and others who fabricated discourse to conceal imperial plundering" (Frohock $2010 \mathrm{~b}, 69)$. Anglophone pirate narrative published in the two decades following Exquemelin's book partook in this discourse. ${ }^{30}$ In these later works, the narrative voices representing Protestant pirates in the Caribbean are stabilized and consolidated as the pirate disappears and is displaced by the privateer as a sign of legitimacy. Buccaneer authors and their editors used new strategies of legitimation-they discontinued the use of the word pirate, dedicated their writings to officials in England, published their accounts as part of collections of travel writing, and presented their actions as an increasingly benign Protestant reconquest in the service of English (and a failing Scottish) imperialism. ${ }^{31}$ Former pirates like Morgan contested representations of themselves as brutal outlaws, legitimizing themselves (and thus also saving themselves from the gallows) as important agents in the context also of a symbolic empirebuilding that rested on gaining the authority of knowledge over the Americas.

In the 1680s and 1690s, a pentalogy of pirate narratives was published in the context of Captain Bartholomew Sharp's plunders, the most 
successful one by William Dampier. In chronologic progression, they develop into travel narratives that hide their piratical context, as their titles demonstrate: Basil Ringrose's The Voyages and Adventures of Capt. Barth. Sharp and Others, in the South Sea: Being a Journal of the Same (1684) ${ }^{32}$ and The Dangerous Voyage and Bold Attempts of Captain Bartholomew Sharp (1685), published as the second volume of Crooke's 1684 English edition of Exquemelin's Bucaniers [sic] of America; Dampier's A New Voyage Round the World (1697, published in five editions within less than a decade and reprinted many times in collected editions [Edwards 1994, 17]), Lionel Wafer's A New Voyage and Description of the Isthmus of America (1699), and Captain Sharp's Journal of His Expedition; Written by Himself of the Same Year. In England, the seventeenth century "saw an ever more successful attempt to bring the pirate into the fold of ... imperial aspirations," which also holds true for the textual strategies to represent the figure (Sherman 2002, 28); Crooke's 1684 English edition of Exquemelin, now dedicated to the rehabilitated Henry Morgan, had prepared the ground for this development. Yet while Exquemelin's transnational narrative voices ambivalence and ambiguity in terms of the narrator's positioning and the articulation of the Caribbean buccaneerpirate, the historical context of an increasing anti-piracy sentiment (and according to laws such as the 1698 Act for the more effectual Suppression of Piracy) ${ }^{33}$ made English privateer-pirates such as Ringrose, ${ }^{34}$ Dampier, or Wafer largely obliterate cruelty and savagery, whitewashing their expeditions into heroic acts of patriotism and exploration and attempting to consolidate the crisis of authority and knowing (Edwards 1994, 22-28). Accordingly, the use of the word "pirate" and even "buccaneer" decreases continuously in these books, and the plundering recedes "behind increasingly inflated characterizations of the conqueror's generosity and benevolent intent" (Frohock 2004, 25); but despite these imperial efforts, even these texts cannot entirely subjugate the dissonant voices of piracy as a coastal phenomenon of the Caribbean contact zone. Read contrapuntally, such efforts at consolidation of a coastal figuration are always already haunted by the voices they try to suppress; the ghost of the Other, pace Derrida, can be found as traces in the text if we read it against the grain. The dissonant voice of piracy as a coastal phenomenon of the Caribbean contact zone does not disappear.

The general historical context for these narratives is fundamentally that of British empire-building and the tradition of British semi-legal piracy since the reign of Elizabeth I, The Pirate Queen (Ronald 2007). 
After the successful destruction of Spanish hegemony in the Caribbeanachieved by the destruction of the Spanish Armada under the leadership of "gentleman pirate" Sir Francis Drake in 1588, English plans to increase its powers in the Americas were not always successful in the course of the late sixteenth and seventeenth centuries. Oliver Cromwell's Western Design (1654) had marked another epochal moment in English expansion that David Armitage defined as "the imperial moment of the English republic," forsaking the more peaceful approach of the Stuarts (quoted in Latimer 2009, 118).

Yet as a campaign, the Western Design was by no means a success in the short term (Latimer 2009, 118; also Frohock 2004, 29-35), the only important addition to the English colonies being Jamaica (1655). In the wake of such failed endeavors during the Restoration, England was supported by the revitalization of her tradition of "gentlemen pirates" à la Sir Francis Drake or Sir Walter Raleigh in weakening the Spanish trading monopoly, but her privateers frequently turned into true pirates going 'on the account' without valid letters of marque or in times of official peace with Spain, France, and Holland, when the English Crown dissociated itself from piracy. The publication of Wafer's account, marking the end point of this chapter, immediately followed the Act for the more effectual Suppression of Piracy and preceded by a mere two years the publication of Piracy Destroy'd; or, A short discourse shewing the rise, growth and cause of piracy of late; with a sure method how to put a steady stop to that growing evil (1701), which construed piracy as a social plague, evoking the ancient accusation against pirates as hostes humani generis:

The practices of such folk were, of course, delinquent and violent, but they had long been so. The appearance of this negative campaign against them in public opinion was not accidental. It coincided with the launching of a new commercial policy of the state, which was directed against French and English pirates naval and judiciary "campaigns" ... . (Pérotin-Dumon 1991, 215)

The late seventeenth-century pirate-privateers collaborated with various populations in the Caribbean, as Francis Drake had with the Maroon Diego (Castillo 1981, 31-43; Campbell 2011, 32-33): the Drake myth of an epic, glorious, and benevolent Protestant colonialism, fortifying the Black Legend (Frohock 2004, 40-44; Hanna 2015, 166), paradoxically helped in the birth of the figure of the uncontrollable Caribbean pirate, a 
somewhat floating signifier without stable identifications or loyalties. The pirates were both essential and a nuisance for the expanding empire as they could be narrativized as vehicles for Protestant providentialism but introduced resistance through the insertion of contrapuntal voices and figures of alterity.

The accounts by late seventeenth-century English adventurers also proudly espouse the collaboration of the pirate-plunderers with autochthonous populations in the Darién like the Kuna and Miskite (Mosquito), who had been known for their successful opposition against a supposedly shared Spanish enemy. As a major theme related with great self-confidence, the representation of such collaborations as mutually beneficent further propagated the idea of a Protestant mission in the New World that legitimized English imperial ventures by constructing a universal rationale for Protestant superiority. ${ }^{35}$ Here, piratical action is for the greater good of empire-building: the pirates become privateers not because they really possessed commissions (or any other form of official support) for their raids, but through the representations of their ventures and moves as patriotic derring-do. In Ringrose, for example, the buccaneers not only become part of the indigenous struggle against Spanish oppression, they even allow Spanish colonizers/settlers, whose bravery is praised $(1685,30)$, to change sides and work with the pirates $(18)^{36}$ : the leyenda negra is thus further de-ethnicized (not all Spaniards are violent and backward) and English/Protestant imperialism is represented as a project for the benefit of the greater good in the Americas, another "Western Design" that also included geographical renaming and other performances of territorial possession (see 51-52). Two Spaniards, Exquemelin had reported in a similar vein, were shot dead for supporting English pirates and taking up arms against their King ([1678] 1969, 125). Dampier, in his account of the first crossing of the isthmus into the South Seas (the "New Voyage"), begins his relations by claiming Miskite allegiance to the English King: "They ... acknowledge the King of England as their Sovereign" and "take the Governor of Jamaica to be one of the greatest Princes in the World" $(1697,11)$; the Kuna are portrayed as eagerly inviting his company as allies against the Spanish:

... [T] he Indians of Darien ... were a little before this become our Friends, and had lately fallen out with the Spaniards ... and upon calling to mind the frequent Invitations we had from these Indians ... to pass through their Country, and fall upon the Spaniards in the South Seas, we from 
henceforward began to entertain such thoughts in earnest, and soon came to a Resolution to make those Attempts which we afterwards did. (180-81)

As Ringrose $(1685,12)$ reports, a mixed buccaneer-Kuna troop seeks revenge for the alleged rape and impregnation of their leader's (called the "King of Darien" in Ringrose 1685, 12, and "Emperor" in Sharp 1699, e.g., 2-4, and Ayres 1684) oldest daughter by a Spaniard. The buccaneerpirates' heroism takes on almost romantic proportions as dutiful and just avengers for the maltreated Indians. Ringrose's first, anonymous publication urges for sympathy with the "miserable Natives ... kept in great subjection": they "do not generate as formerly, though they are a stout people, and have amongst them good comely Women: the reason of it, as we conjecture, is, the depressure of their Spirits, by the tyranny of the Spaniards ...; the means of Propagation not taking its natural effect upon people so absolutely dejected with oppression, as they most certainly are" $(1685,69)$. But while Dampier constructs a commonwealth in which "Indians" participate, acknowledging Charles II as their sovereign, the titles of "King" and "Emperor" in Ringrose and Sharp suggest otherwise $^{37}$; Ringrose's first account even turns around the power relations in his preface, claiming that Sharp's exploits were made "in service of the Emperour of Darien" (n.p./A2) Andreas; in fact, Sharp plundered in Darién with a commission from the deputy governor of Nevis (Hanna $2015,156) .{ }^{38}$

Perhaps the best known and most significant narrative in the context of 'scientific' piracy, Dampier's New Voyage Round the World is emblematic of the buccaneer's domestication. "The most celebrated seaman between Drake and Cook" (Sherman 2002, 29), Dampier, born into a farming family, became a "New World Upstart," helped manage a plantation in Jamaica, worked with log-cutters in Campeche, Mexico, plundered as a buccaneer, and, after his return to England in 1691, published the New Voyage, whose "clear prose and keen ethnographic eye placed [Dampier] squarely among those Restoration scientists who valued direct experience ... ."39 Dampier dedicated his book to the Royal Society's president, emphasizing his own "hearty Zeal for the promoting of useful knowledge, and of any thing that may never so remotely tend to my Countries advantage" (1697, n.p./A3) in a dedication, Dampier expressing his hopes that he will be judged "capable of serving his Country, either immediately, or by serving you"; he included maps (e.g., Fig. 2.2) and lengthy nautical and hydrographical parts in subsequent editions of his Voyage, all of which 


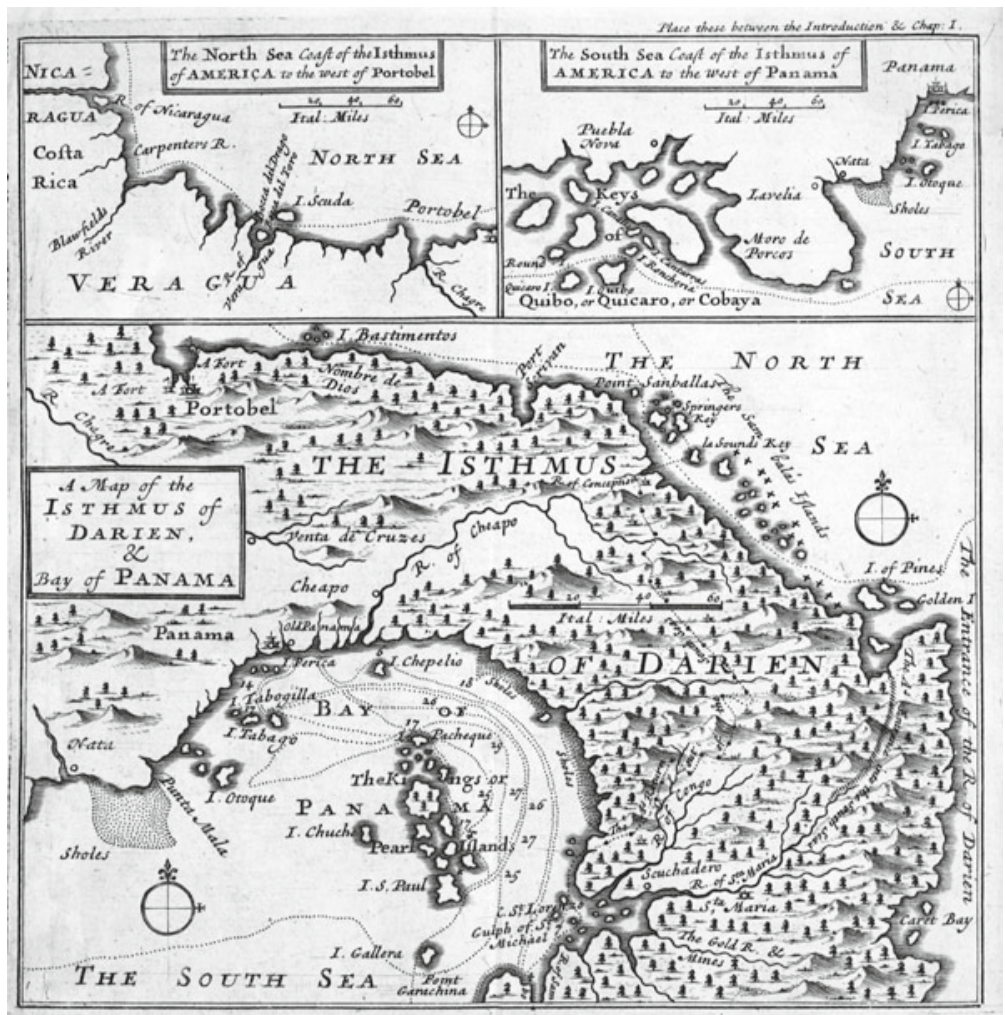

Fig. 2.2 Map of the Isthmus of Darién and Bay of Panama, from William Dampier's New Voyage Round the World (Courtesy of Linda Hall Library)

eventually rewarded him with the command of a South Sea expedition and the selection by Woodes Rogers as navigator for his circumnavigation under Queen Anne. In this context, Johns (2009, ch. 3 ) as well as Craciun (2013, 174-75), who explores Dampier's publications from the perspective of a book historian, refer to a "piratical enlightenment" that began with the expiration of the Licensing Act in 1695, allowing for a fifteenyear period (until the copyright Act of 1710) of unlicensed publication of piratical-scientific adventure books. 
Dampier had fought with the Royal Navy in 1673, but after a battle wound and further turbulences joined the buccaneer Captain Sharp in 1679. The discourse of his narrative is the most scientific of the texts considered in this chapter, thereby also evading the sign of piracy: "As for the Actions of the Company, among whom I made the greatest part of this Voyage, a Thread of which I have carried on thro' it, 'tis not to divert the Reader with them that I mention them, much less that I take any pleasure in relating them" (1697, n.p./A4). The pirates are reduced to a "Company" here, and sensationalist appetites of spectacular battles and tortures are quenched in favor of scientific description; this metatext clearly positions the intended audience as interested in science, not sensation. (Still, the book became highly popular, as Willard Bonner has shown, and made Dampier famous; 1959, 34-36.) In this vein, Dampier also adds that this shift of focus, however, "would not prejudice the Truth and Sincerity of my Relation, tho' by Omissions only." Thus Dampier fashions himself as the scientific imperial protagonist, dissociating himself from the buccaneers and presenting himself as a man of letters, and distinguishing between "Actions" (perpetrated by his traveling companions) and his own role, limited to the task of "Chorographical Description" (1697, n.p./A4; see also Edwards 1994, 30): Dampier says that he reluctantly writes about piratical adventure and assures his readers in his Preface that pleasure (his own or the readers') is not at issue here, distancing himself from the sensational taste for pirate stories of his day. At the same time, he needs the pirates for his audience's critical, methodological "satisfaction" in order to establish a credible context. ${ }^{40}$

Numerous revisions and editions have turned the text increasingly in this direction of science writing (Frohock 2004, 93-94; Lane 2007). The Sharp pentalogy's various efforts at silencing criminal agency (the prime context of the narrative) are not as innocent as they may seem, however, considering the fact that this editorial policy leads to the concealment or euphemizing of the rape of sixty enslaved African women on a Danish slaver the crew had taken as a prize and cynically renamed "Batchelor's Delight" (Lane 2007; Franklin 1992, 244). Read against the grain, the sheer number of "Indian" and "Negro" slaves mentioned as well as their numerous attempts at escape and mutiny are telling the reader enough about the conditions of the enslaved (e.g., Ringrose 1685, 155, 159, 165; Kuhn 2010, 65). Unsurprisingly, scholarship has commented little on Dampier's involvement in the slave trade, or the fate of the "painted 
Indian" he brought to England and planned to display for profit (Munter and Grose 1986, 423), for that matter. ${ }^{41}$ It tends to present discovery and adventure as European feats, neglecting the navigators' complete reliance on native guides that is voiced throughout the Sharp pentalogy. Instead, Dampier became famous overnight after the publication of his Voyage, was lionized by Samuel Pepys and Sir Hans Sloane, and is remembered today as a national hero; his portrait is part of the National Portrait Gallery and his "discoveries" have remained national lore: "From the start Dampier was known, not as just another Esquemeling [sic] ... but as a man of dependable knowledge gained from varied experience" (Bonner 1959, 32).

Nevertheless, Dampier's silences are ruptured because he needs context and circumstance to authenticate his narrative; the coastal sign of the pirate disturbs the slick account of the Voyage. Especially in the first edition, similar to Ringrose and Wafer, the amount of African and indigenous exploitation (1697, e.g., 2, 158), references to blank or fraud commissions (e.g., 39, 45, 68, 192), and the suspicion that autochthonous groups had interests different from the buccaneers' (arising in the context of the narrator's obligation to explain either their collaboration or hostility, e.g., 11, 13) yet again evoke epistemological insecurity, a consciousness of difference, and a crisis of trust and comprehensibility. Dampier and his peers present a mixture of science and colonial propaganda - and with it, disturbing the main discourse, colonial horror and aversion. Fear of rain, of mutinous slaves, of starvation; the feeling of being "at a loss" (e.g., 13, 163, 252, 309); reports of drowning, hanging, and abandonment pervade the text.

An ethnographic anecdote from Lionel Wafer's New Voyage highlights the limits to the ethnographic/scientific curiosity that increasingly shaped the discourse about cultural contact on the Caribbean coast and the American isthmus, with its "legendary aura as flowing with gold and silver" (Latimer 2009, 210) in pirate literature. While "Indians" in Exquemelin are represented in many subject positions-savages, Spanish collaborators, friends, allies, useful workers, informants, and 'authentificators' for the buccaneers-Wafer describes them in extenso out of a primarily ethnographic interest in a discourse of scientific exoticism (see Barnes and Mitchell 2002). Prominently placed in the middle of his narrative, Wafer describes the high occurrence of albinism among the Kuna: 
There is one Complexion so singular, among a sort of People of this Country, that I never saw nor heard of any like them in any part of the World. The Account will seem strange, but any Privateers who have gone over the Isthmus must have seen them, and can attest the main of what I am going to relate; tho' few have had the opportunity of so particular an Information about these People as I have had. (1699, 134)

Apart from its symbolic act of legitimation (using the designation of "privateers" and thus legalizing their actions post-festum so as to produce a favorable public opinion at a time when anti-piracy campaigns successfully shifted public opinion about pirates to the negative), the quote also shows how ethnographic description at the end of the seventeenth century had to bridge discourses of sensational discovery, most attractive for a metropolitan readership, and scientific credibility. There was a paradox between a desire for auctorial self-marketing as rare eyewitnesses of often spectacular events and facts (like light-skin "Indians") and the necessity of supporting testimonials in order not to be discredited as delirious or fantastical. As Steve Clark points out:

The travel narrative is addressed to the home culture; by its very nature, however, that to which it refers cannot be verified, hence the ready and habitual equation of traveller and liar. This in turn requires the production of counter-balancing stratagems of sensory corroboration and complex decorums of witnessing, whose innovative plain style prefigures and is assimilated into the early novel. $(1999,1)$

Readers were indeed inclined to discount travel narratives reporting exotic or spectacular matters (Frohock 2010b, 59), a fact that had to be countered by travel writers. Among the narrative strategies developed in this context, Clark mentions hyper-empiricism, the illusion of an experiential present, and gestures of trustworthiness $(1999,2)$; the authority of experience is often present in hyperbolic form. Consider, for instance, Exquemelin's report on the caiman: “... this I have seen for myself. I shall set down a few more of the observations I have made on the cayman, for I doubt if any of the authors who have written of these reptiles have ever had such experience of them as I have" ([1678] 1969, 45); a few lines later, he again repeats "This I have seen myself" (46); again on the very next page, the narrator reports that "[a] hunter was once the cause of my seeing something so amazing I'd have been unable to believe it if anyone 
else had told me the tale" (47). Invoking the authority of presence and experience by referencing the seeing as knowing (Hartog 1988, 273) is but one strategy of creating credibility, however. In the context of the need for supporting testimonials, native inhabitants are utilized by both Exquemelin and his successors - transcending the latter's national historiographic framework-because they are often the only available witnesses. In the case of Wafer's account of the period he spent apart from his group among the Kuna (who helped him cure his battle wounds and allowed him into their society) this is even more pertinent, as he is the sole white person to "give an account." 42 Such native groups are constructed discursively as noble rather than as ignoble savages, since they are presented as collaborators rather than enemies: the Kuna are emphatically nobilized (they have "Kings" or "Princes") and thus their credibility is enhanced as the narrator's principal witnesses. Authorial credibility was thus dependent on a representation of autochthonous people that was strategic rather than scientifically objective.

But this strategy ultimately cannot contain dissonance and hermeneutic gaps. For an explanation of the phenomenon of albinism, for instance, Wafer inserts the voice of the Kuna "Chief" $(1699,132)$ Lacenta, one of his native informants, in reported speech quotations: children who were born white came to be so "through the force of the Mother's Imagination, looking on the Moon at the time of Conception" (138). Wafer gives no further commentary, neither affirming nor deriding this explanation, but instead explicitly asking the reader to do so. The representation and translation of cultural difference is halted by the coastality of knowledge-indigenous belief-systems and a European science mediated by an in-between agent struggling for a narrative authority he does not have in this scenario. Compared to the other texts examined in this chapter, the discourse of cultural contact is less violent here, and rather full of speechlessness and awe, evoking Stephen Greenblatt's description, in Marvellous Possessions, of the reaction of wonder in cultural contact scenarios. This can be explained by the fact that Wafer is the only one of these authors who actually 'went native,' living with the Kuna for some months and adopting their fashions and body-paintings, while he was ailing from an accidental gunpowder explosion that had severely damaged his knee. His account is shaped by repeated claims to an authority of experience, having lived with the "Indians" and participated in their daily lives, their feasts, and hunting expeditions. 
In such coastal contexts, neither here nor there, Eurocentric scientific categorization is suspended, as the narrative is entirely dependent on its Kuna informant, whose account is beyond the control of authorial calculations. Such native knowledge constituted the actual basis for the mapping and categorizing of the Americas, its populations and environments, serving imperial/colonial interests. In a contrapuntal reading, both the incorporation of native voices like Lacenta's and the suppression of cognitive dissonance can never be complete and can never purge the narrative from irreducible difference. In this view, ennobling the Kuna leaders through the use of western titles of nobility is only a narrative crutch: the European narrator-protagonists cannot look inside the indigenous mind, "knowing" whether their "Information" was correct or whether their interest was another, such as deceiving or mocking the European adventurer. As Michael Taussig has examined in detail in his study of the mimetic arts of the Kuna in the colonial scenario, this was a frequent strategy employed by the colonized. ${ }^{43}$ In his words, "the tale of Lionel Wafer ... shows just how Darién Indians succeeded in taking advantage of the rivalries between European nations and of the instabilities of the European frontier" (1993, 137).

According to Exquemelin's interpretation of the "Indians" distrust of strangers, the Spaniards introduced suspicion to a formerly harmonious society in the Americas:

In my opinion, the reason why the Indians shun all contact with strangers is that when the Spaniards first came to this country they subjected the inhabitants to such cruelty they looked on the conquerors with terror. ... After their experiences they dare trust no white men, looking on them all as Spaniards. Indeed they could not trust the other Indians even, for some tribes had taken sides with the Spanish, and cruelly tormented their fellow country-men. ([1678] 1969, 214)

Moments of doubt are pivotal for a contrapuntal reading of colonial relations and cultural contact. In all four narratives mentioned in this chapter, doubt about the trustworthiness, predictability, and calculability of autochthonous subjects and of second-hand information in general play an important role as moments of crisis-in the deliberation of further action or course, but also in narrating. The "Barbary ape" episode in Exquemelin is symptomatic here: a Spaniard, the author-narrator reports, had told him "of a sort of people who live in these mountains, of the same 
stature as the Indians, but with short curly hair and with long claws on their feet, like apes. Their skin resists arrows and all sharp instruments" (97); apparently, they had never been heard to speak and captured Spanish women as slaves. Exquemelin calls them "wild men" following several Spaniards who "assured [him] that these creatures are human, and that they have seen them frequently: I give it here for what it's worth. Truly, God's works are great, and these things may well be." Perplexed with skepticism and incredulity, the narrator returns to a mythic, religious worldview incompatible with his empiricism regarding more knowable and believable facts. ${ }^{44}$

The pirates themselves are also shown to play with the colonial crisis of epistemological reliability in their freewheeling use and barter of letters of marque and of national symbols such as flags, both of which they usually had in store in multiplicity. In the repetitive performance of mock battles, treachery and deception, and what I call national crossdressing (i.e., the use of "flags of convenience," Langewiesche 2004, 5) in Exquemelin and his successors (e.g., Ringrose 1685, 4, 94, 123), they disturb the signifier/signified-connection, exposing its conventionality and thus upsetting categorizations on which economic and military relations in the Americas relied. The cross-dressing of ships also echoes the cross-dressing of women as pirates in history and literature that literary critic Marjorie Garber has famously analyzed as signifying crisis-both in terms of gender roles and other cultural differences (see Sect. 2.2).

Such moments of doubt and insecurity are typical indicators of epistemological crisis at a time in which, as Ralph Bauer has argued in reference to Stephen Shapin, traditional trusting systems had come into crisis through an "inflation of empirical knowledge, accelerated by mechanical reproduction through print" $(2003,4)$. The turn to the eighteenth century also marked the turn from an earlier naïve empiricism to an extreme skepticism (10, in reference to Michael McKeon). Thus the great cultural investment in modern science as the building of an empire of truth, an "epistemic mercantilism" in Bauer's phrasing:

The poetics of this mercantilist production of knowledge demanded a division of intellectual labor between imperial peripheries and centers, the effacement of colonial subjects, and the transparency of colonial texts as the providers of raw "facts." ... In theory, these imperial economies of knowledge production thus resembled the mercantilist economies of material production, based as they were on a regulated and protected balance of 
exchange ... . In practice, however, these imperial epistemic economies ... existed but as logocentric utopias that engendered their own modes of geopolitical resistance and were frequently undermined by colonial subjects. (4)

\subsubsection{The Creole Pirate}

Science, Richard Frohock demonstrates, was a new path for representing British engagement with the Americas, having considerable power in displacing, but in many ways also replicating, the image of the conqueror $(2004,81-82)$. It is in this context that we have to view Anna Neill's argument that the buccaneers are increasingly domesticated in the narratives succeeding Exquemelin's as scientific agents; the ethnographic, geographic, and nautical parts far outweigh violent episodes of combat, and the pirate turns into a scientist out on an expedition in 'the field':

Such literature at once illustrated the condition of human beings in an earlier "pre-civil" state, and at the same time suggested that it is less might than civilized reason that determines entitlement to colonial territories and resources. Although by the very violence of their actions, the buccaneers $\ldots$ had confounded this distinction between civilized colonizer and savage colonized, the increasingly direct interest of the state in scientific discovery in the last third of the seventeenth century had the effect of bringing them more closely into the fold of civilized statehood-either as objects of its disciplinary control, or ... as reformed, re-civilized sovereign subjects and men of science. $(2002,166)$

Yet the pirate does not emerge as a glorified figure in any of these texts; Exquemelin in particular shows "intonations of scorn and irony" (Frohock 2010b, 62-even though this does not necessarily lead to "the reduction of buccaneer civility to nothing more than a ploy," as he concludes). Excess and squander ("economic follies," 65), brutality and solidarity stand next to each other as colonial paradoxes beyond authorial control. The narrative tensions in Exquemelin certainly make the book appear more effectively critical of piracy and colonialism, on the level of representation, than Dampier's or Wafer's, who had no interest in criticizing English expansion, as Exquemelin "creates a novel socioideological platform for contesting the multiple languages competing to represent the imperial Caribbean world. The effectiveness of his cultural critique depends less upon making his own truth unassailable than 
on interrupting, contesting, and destabilizing the discourses of others through his distinctive portrayal of the buccaneers" (57). But is this effect really as intentional as Frohock suggests?

The sign of piracy, entailing uncontrollability, (ab)errancy, and unreliability, returns even in the imperial travel narrative based on buccaneering expeditions such as Captain Sharp's. These contrapuntal signs can be seen as indicative of an early creole discourse, ${ }^{45}$ voicing resistance to metropolitan colonial epistemologies of order in response to the unequal power relations between New and Old World economies of knowledge: "the colonials in the 'bowels' of nature would provide the epistemic raw material, and the metropolitan natural philosopher would refine it into "truth" (Bauer 2003, 17; also Ordahl Kupperman 1995). In this sense, the sign of the pirate also entailed the piracy of knowledge (Bauer 2003, 160) —indeed, often the most valuable piratical booty were letters, notes, accounts, charts, maps, and oral information (171); yet contrapuntally, the proto-creole pirate questions the legitimacy of a metropolitan monopoly over knowledge claimed by the agents of the new sciences when he asserts his narrative authority and emphasizes his privileged position vis-à-vis the European as a first-hand witness and informant. Resistance is less an act of authorial or narrative intention, then, than a form of piratical disturbance of the new logocentric imperial claims.

\subsection{Puritans and Pirates: The New England Anti-Piracy Sermon, I700-I730}

\subsubsection{Piracy in New England}

Piracy was not limited to the Caribbean coasts at the turn to the eighteenth century. It declined during Queen Anne's War (1702-1713), but was again on the rise in the entire Atlantic World after the Peace of Utrecht in 1713, which left many sailors formerly employed by European navies without income, some of them turning to piracy. A second North American context in which the sign of piracy was used in an attempt to consolidate crisis was the "maritime civilization" (Fernández-Armesto 2003, 59) of Puritan New England, where it had become an increasingly visible phenomenon as many pirates shifted their activities northward when the Caribbean waters became too tightly controlled (PérotinDumon 1991, 215). In a handful of publications which tackle the issue of piracy directly-printed execution sermons ${ }^{46}$ about condemned 
pirates that were increasingly prefaced or appended by confessions, warnings, dialogues, or factual accounts-Cotton Mather (1663-1728), ${ }^{47}$ the renowned Puritan minister of Massachusetts Colony and one of the most influential public personae of his day, reacted to the increasing number of New England piracy trials by warning against the disruption of the religious and social order of the colony, a concern that ran deeply in his generation of Puritans. The turn from the seventeenth to the eighteenth century marked a time of crisis in New England, as the new charter in 1692, following the Glorious Revolution of 1688, sought to tighten control over the colony by appointing royal governors in England. This development had triggered an atmosphere of political turmoil and division among the settlers; in the context of religion, a spiritual crisis had already led to a watered-down, "Half Way Covenant" in 1662, accounting for a younger cohort of colonials two generations removed and increasingly failing to meet the standards of the original conversion experience. An increasing commercialism, accompanying the expansion of the colonial settlements after King Philip's War (1675/1676) and the growth in population, similarly provoked anxiety and fear about the (exceptionalist) vision of Puritan America as a New Jerusalem and a City Upon a Hill (John Winthrop) that was to be a better version rather than an imitation of European social structures. While the "Indian" had emerged as a figure of alterity in Puritan conversion texts-his/her conversion could never be fully trusted as his/her capability thereof was doubted, the pirate emerged as the latest figure of crisis. He embodied the first crisis of white conformist masculinity and appeared as an in-between figure that was capable of conversion but at times would prove inconvertible. Accordingly, he was constructed as an ambivalent figure in the context of a heavily racialized and gendered Puritan rhetoric, a secular figure of illegitimacy whose containment by Puritan discourse was needed to reaffirm conceptions of an exceptional American male subjectivity in a transatlantic colonial-imperial continuum. "As one crisis followed another," Williams argues, "New England churches, instead of withdrawing from the world, embraced it" $(1986,830)$; the pirate constituted one such secular embodiment of a sinful world the ministers attacked. ${ }^{48}$

In this chapter, I am reading Puritan anti-piracy sermons as narratives of crisis that, despite fervent efforts of containment in the context of a much-needed reaffirmation, exceed these efforts by a hybrid narrative dynamic resulting from the use of sensationalist elements, piratical 
voices, and economic discourse. I am arguing that the popular, widely received sermons by Cotton Mather and Benjamin Colman examined in the following are pervaded by energies of resistance that could lead their readers to sympathize with, instead of merely condemn, the piratical questioning of social and religious authority as well as economic legitimacy-especially in a theocratic environment that exerted an "iron-clad hold on local printers, who could not print the 'trash' that characterized the secular crime literature of England" at least up to the period of "Anglicization" (Crosby 2010, 8; see below); New Englanders thus habitually used to "feed their desire for crime writing by turning to ministerial pamphlets."

\subsubsection{Cotton Mather's Anti-Piracy Sermons}

Published between 1704 and 1726, Cotton Mather's anti-piratical execution sermons functioned as didactical instructions for actual pirates to repent, for sailors to be deterred, and for his congregation to extol piracy as sinful and spiritually destructive. Printed so that they would reach beyond Boston, "to Rhode Island and Carolina, to England and India" (Hanna 2015, 253), crime narrations like the pirate execution sermon became discourses to promote law and order, imposing "structure on socially disruptive experiences" and "negating the misrule inherent in unlawful action" (Williams 1993b, xi). In practice, Mather frequently tended to pirates sentenced to death in order to lead them to redemption and save them from hell: in his Diary, we find him taking "a long and sad Walk" with the condemned, "from the Prison, to the Place of Execution," along which he "successively bestowed the best Instructions [he] could, upon each of them"; arriving at the gallows pole, he prayed with them and the "vast Assembly" of spectators $(1717,1957,488) .{ }^{49}$ Daniel Williams sees Mather's anti-piratical activities as a response to the tendency of New England sailors to turn pirate to such a degree that Boston was called a "New Algiers" already in 1689 (in reference to the early modern Barbary 'piracy'; Edward Randolph quoted in Hanna 2015, 182). Three years earlier, Increase Mather openly acknowledged colonial complicity with pirates in a sermon entitled Solemn Advice to Young Men: Not to Walk in the Wayes of Their Hear, and in the Sight of Their Eyes; but to Remember the Day of Judgment that was reprinted, not coincidentally, in 1709 (53; see Hanna 2015, 251). Now, 
[t]o counter this tendency, [Mather] sought to make special examples of all condemned pirates in Boston jails ... . But while he worked to save pirate souls from the fires of hell, he was as well attempting to reaffirm the same social and religious values that the pirates had first defied. Aware of the immense public fascination with the spectacle of execution, Mather used those about to be 'turned off' to illustrate the futility of sin and the inevitability of judgment. (Williams 1987, 235)

Metaphors of mobility and shipwreck inform most of Mather's antipiratical sermons. This range of verbal imagery can be linked to both the 'life is a journey' metaphor of the Scriptures and the "departure of God" rhetoric, which, together with metaphors of sickness, deprivation, and loss, was used by an earlier generation of Puritans responding to generational conflict and spiritual crisis (Elliott 1975, 99). Yet the journey across the Atlantic was of course also the foundational experience for the Puritan project in the New World; John Winthrop's "City upon a Hill” speech aboard the Arbella as well as Danforth's "errand into the wilderness" have been seen as the basis for its mythology (Wharton 1992, 45). Reflecting also the increase in the seafaring trade after 1640, the language of the journey and of seafaring was an important resource for Puritan preachers, even though the colonists themselves hardly had a seafaring background (McElroy 1935, 331-33). ${ }^{50}$ For the Puritans, the space of the Atlantic was symbolically loaded, as successful voyages were seen in the framework of what Udo Hebel calls the Puritan "providential hermeneutics" $(2004,17)$ : as a "sign of providential protection, of spiritual, later patriotic, fitness," making "sacred what was otherwise secular space" (Wharton $1992,47,52$ ), while shipwreck and piracy were framed as signs of a fall from grace. The Atlantic scenario thus became the Puritan "trial by water" (also Hebel 2004, 15-16). ${ }^{51}$

In accordance with this symbolism, Mather conceives of sinners as "pursueth by Evil" and "Runawayes" $(1723,19)$ in his Useful Remarks; they are "Fugitives when they leave that Master," Jesus Christ (20). These metaphors also express the ideal of spiritual steadfastness that is Mather's concern in his endeavor to renew New England's covenant with God. Mather's third-generation Puritan outlook somewhat paradoxically seems to return to earlier lamentations of aberrance and transgression in these sermons, which often contain elaborate lists of sins and failures. The increasing bitterness of Mather's rhetoric, gradually approaching that of his father Increase, points to a significant cultural shift (Bosco 1978, 
170): Mather's anti-piratical execution sermons as well as other sermons directed explicitly at sailors addressed the condition of the New England covenant and the future spiritual estate of the young; they sought to guide an increasingly transnational tribe of seafarers in the Puritan spirit, but that spirit continued to lose its powerful grip on the colony at the turn of the seventeenth to the eighteenth century. ${ }^{52}$

Of course, the genre per se afforded the threat of damnation and the admonition to repent, and Mather and others routinely used the "[d]ying words of a Malefactor" (Warnings 42) in closing, often in direct speech for a heightened effect of immediacy, in order to extol an example of repentance for other sinners in their audience. Not surprisingly, these sermons are less in tune with Mather's "language of assurance" (Elliott 1975, 188); the frequent use of exclamation marks and italics in an otherwise "plain style" (Cohen 1993, 7) are used as markers of an almost desperate insistence, betraying Mather's emotional involvement in the conversion of the "poor condemned Pyrates," as one of many singleline entries in the minister's Diary has it $(1957,729) .{ }^{53}$ Yet his earlier sermons also emphasize the glory of a God whose benevolence could be reached by sincere repentance, even if that repentance came only minutes before the actual execution. The appearance of a benevolent and merciful rather than fearful deity aligns the younger Mather with the spiritual shifts of the late seventeenth century from pessimist visions of impending doom to a more optimist millenarian version of New England's destiny (Elliott $1975,177-78$ ). Mather's work on piracy, even though it turned increasingly bitter, resonated with his introduction of the "new theme of national salvation" (191) into Puritan discourse, comparing New England favorably with the rest of the world and warning the community of repeating old-world mistakes. This is exemplified by the fact that the choice of condemned criminals to demonstrate the steps to salvation was unique to American Puritans (Williams 1986, 831).

\subsection{3 "To Direct the Course of Sea-Men"}

The desire for social stability and the reaffirmation of existing hierarchies is expressed by Mather's repeated advice that the colonial American subject follows the Calvinist doctrine of predestination not only in religious terms but also in terms of social status. As Mather has one of his repenting pirates advise: "Stay in your Place \& Station Contentedly, \& be Thankful to God for all things that happen to you" (1723, 33; 
station signified both a sailor's function aboard ship and his place in society). The conflation of social and geographical mobility in Puritan discourse is significant also in the context of Puritan migration and expansion, including the transatlantic recruitment of immigrants for settling the backcountry in the relatively peaceful decades after 1713 (Conforti 2006, 133-37): God-governed and state-sanctioned mobility is crucial for the development of new Puritan communities in Mather's texts, while piracy is constructed as illegitimate in its aspirations to free the subject from the Calvinist providential order. In Mather, piracy becomes a trope to set the outer boundaries of legitimacy in terms of trade, mobility, and subjecthood for an entire community.

Mather's aggressive marketing of his books and pamphlets, noted by Daniel Cohen, specifically targeted ships when he gave numerous free copies to ship's officers for the benefit of their sailors $(1993,5)$. In 1700, Mather preached a sermon entitled The Religious Marriner. A Brief Discourse Tending to Direct the Course of Sea-men in those Points of Religion Which may bring them to the Port, of Eternal Happiness to the sailors of Boston. In the printed version of this speech, the minister uses metaphors of mobility to guide the sailor and lead him on the "right course," a discourse also used in the execution sermons (e.g., $1717,36)$. Right in the preface, Mather acknowledges the importance of the site of sailor existence in the formation of collective identity, as he addresses his sermon to a new oceanic collective, a "Sea faring-tribe" (4) the author calls "the Waters" in an explicit parallel to "the Grecians" and "the Romans" (3). In fact, Mather argues that sailors "at all times ... bear [Resemblance] unto the Waters, upon which they are now Sailing"; "their Living on the Waters Entitles them to this Denomination, just as a Country or City, gives a Denomination to its Inhabitants." This comparison of course does not lead Mather to treat sailors as subjects of a different country, to different laws and ethical codes; paradoxically, it is the fact that they are at home on the sea rather than land-based that builds the center of his warning, as the influence of the seafaring environment on the sailors' moral character forms the central topic of this work. This choice can be read as a reaction to the ever-growing seafaring population since the mid-seventeenth century, whose mobility was perceived as a threat to colonial society. As McElroy argues somewhat polemically:

When [young men gone to sea] returned home, they found life dull and prosaic; more than ever, the ocean seemed the gateway to freedom. ... Avarice or ambition rarely sent any boy to sea; most of them were thinking 
of the adventures of every Jack-tar acquaintance and his yarns about 'rivers of rum, mountains of sugar, and fish that fly in the air.' $(1935,334-35)$

The increasing population of sailors was in dire need of spiritual guidance in Mather's view. In accordance with his self-fashioned righteousness and megalomaniacal pride, ${ }^{54}$ the title page of Mather's Religious Marriner quotes Matthew 14, 25: "Jesus went unto them, walking on the Sea"; Mather positions himself as the savior of a people drawn to sin through seafaring customs - drinking, swearing, adultery, and other "special vices of the sea" $(1700,14) .{ }^{55}$ In an act of interpellation that, to some extent, creates the stereotypical pirate rather than merely reporting him, Mather's prose characterizes seafaring as "riotous living" and the sea as a "school of vice" (5), an observation that the minister claims to reach back to Plato. Preaching to an audience of sailors of New England, the minister warns against "those false courses of $\sin$ " (7), emphasizes the sailors' importance for the Commonwealth under the auspices of a sense of Protestant mission (Mather complains of the "Sinful Neglects of the protestant Nations to make their Navigation, Subservient unto the Illustrious Design, of conveying the Knowledge of the most Glorious Lord, unto all parts of the Universe," 10), and urges his audience to be "faithful in Christ, where alone, your Souls may be Anchored with Eternal Safety" (10). Other metaphors similarly connote mobility as dangerous, direction as crucial, and sessility as preferable: "steer clear of the Sins," "Depart from Evil" (14), “don't go out of the Way, when you Go to Sea” (19). Admitting the importance of seafaring for the British colonial empire, Mather sees it as a necessary evil:

Truly, 'Twere much to be advised, That the Enchantments of the Sea, may not have too strong and quick a Force upon some, to make them rashly leave Good Callings, by Which they might competently subsist ashore. I am far from condemning all that leave their Callings, and go away to Sea; but this we have seen, where one hath Advanced himself, more than two have Ruined themselves, by doing so. (20)

Before continuing his sermon with a long prayer fashioned for the sailors to imitate aboard ship, Mather warns against "bloody Murderers, Pyrates, and Atheists ... . There are some, in such Ill Terms with Heaven, that if one could help it any way in the World, one would not care to carry them: 
Tis no safe thing, to be of their Mess!" (21-22). Adapting his vocabulary to the imagined violence of seafaring life, Mather's sermon draws on and enforces the spectacular representation of pirates as "the worst Enemies ..., who barbarously butcher all that may discover them" (30). The exhortative sensationalism of his rhetoric carries much emotional appeal through the use of such graphic verbal expressions, italics, and exclamation marks.

Indeed, the representation of pirates as killers who did not distinguish between friend and foe served the official politics of the day that realized plunder was only a minor aspect of the pirate threat; more dangerous to imperial mercantilism was the fact that many sailors of the Royal Navy or the Merchant Marine, coming into contact with pirate crews, did not have to be forced to join them-to the contrary. The attractiveness of piracy for mistreated sailors was the main incentive for the blatant didacticism of Mather's preaching. The inclusion of speeches by repenting pirates, a feature the execution sermon shares with the jeremiad, was geared toward a younger generation that was to be reminded of the importance of the covenant (Bosco 1978, 168-69); after all, the Puritans were convinced "they would be held collectively responsible for the wrongdoing of individual members" (Cohen 1993, 7). Thus, ministers preaching execution sermons warned young men from a sinful course of life that would lead to the gallows, but also endanger the entire New England colony. In Useful Remarks (1717) Mather directly addresses the young men and sailors of Rhode Island, exhorting them that death is preferable to changing to the 'wrong' side: "Rather Dy, than go With, or do Like such Wicked men. My Son, If such Sinners Entice thee, Consent thou not unto them. No, Rather Dy than do it!" $(1717,22)$. The narratives annexed and appended to these sermons-speeches and letters dictated or written by the condemned pirates and sometimes "Faithfully Collected, by Another Hand" (29)-also serve this function (see also 37, 39, 41), as Mather and his publishers seem to hope for heightened effect. In 1724, Mather's diary relates the power of the pulpit (Elliott 1975) in one case of piracy. The entry is suggestive of Mather's belief in himself as a catalyst to bring about godly justice and besiege the pirates:

I was carried forth to pray in an enlarged and expanded Manner, and with much Importunity, that we may see the glorious One do some remarkable Thing for the Destruction of the Pyrates, by which our Coast has been lately infested. The Prayer had so much Notice taken of, that many 
People receiv'd and expressed strong Expectation from it, that within a few Days, yea, before the Week was out, we should hear something remarkable. Behold, before the week was out, there comes in a Vessel wherein five or six Captives among the Pyrates that were upon making horrible Ravages among our poor Fishermen, rose, and with much bravery kill'd the Chief of their Masters, and the rest they took Prisoners. The Joy of the City on this Occasion was very notable. $(1957,722)^{56}$

Mather might have exaggerated his own role here, but there is no doubt that both his spoken sermons and their printed versions, sponsored by friends and parishioners, were highly successful. The latter often sold as many as a thousand copies a week and ran through a number of editions; obviously, his instructions reached many New Englanders (Levy 1979, 39; Minnick 1968, 80). The printed sermons were usually written versions of Mather's extempore preaching, and many were elaborated with additional material and notes, but they closely echo the spoken versions. Other genres relevant for Mather's anti-piratical discourse, like the essay, also bore a direct relation to his preachings, as they rehearsed earlier arguments and pleas from the pulpit.

Mather's interest in piracy is not limited to his published works, as mentioned above; his extensive diary informs us of the context for his anti-piratical preaching. The first reference to piracy occurs in 1696, in a jeremiad-like list of grievances and failures of the colonies: "Some that have belonged unto this Countrey, have perpetrated very detestable Pyracies, in other Parts of the World" $(1957,215)$. Because piracy transcends the local, Mather likewise transcends his usual focus on New England society and the purity of the colonial community, linking "this Countrey" to "other Parts of the World," although the use of the present perfect tense makes it clear the pirates no longer belong to the imagined community of Mather's New England. ${ }^{57}$ By the turn of the seventeenth to the eighteenth century, Mather had started to visit condemned criminals awaiting their execution in Boston jail. In April 1699, he mentions the "great number of Pyrates" he encountered during one of these visits; he "went and pray'd with them, and preach'd to them" (299), using Jeremiah 2, 26 ("The Thief is ashamed, when hee [sic] is found"); another such occasion is mentioned for January 1700, again making use of Jeremiah (17, 11: "He gets Riches and not by right; leaves them in the midst of his Dayes, and in his End shal be a Fool"; 331). 
The Diary does not mention the "Tragical Spectacle" of the hanging of some pirates in Boston on June 22, 1704, on which the execution sermon Faithful Warnings to prevent Fearful Judgments is based, a lengthy appellation that directly addresses the "sinful" pirates, preaching repentance before they are punished. The sermon, subtitled Uttered in a brief Discourse, Occasioned, by a Spectacle, in a Number of Miserables Under a Sentence of Death for Piracy, sets up a strict dichotomy between the wicked and the righteous while paradoxically acknowledging, in accordance with Calvinist doctrine, the principal sinfulness of every person (1704, e.g., 5-6). Mather further distinguishes between penitent and unrepentant sinners (7) and again, devises a list of sins, which includes poverty as a consequence of men being "not Rich towards God" (10), but also a number of "Lusts" such as intemperance, "Unchastity," covetousness, and "Earthly-mindedness" (12). Mather theocratically conflates earthly and heavenly punishment by invoking the "Law of Death, for Capital Crimes" (13) on both a secular and religious level throughout the sermon: ${ }^{58}$ "our pirates," Mather argues, have tried to hide themselves "in the Bottom of the Sea," but "wherever they hide themselves, I will search \& sieze [sic] them, saith the Lord" (23). What in fact searched and seized the pirates, of course, was less "the Lord" than the law. Although Mather uses religious discourse and appeals to the conscience of criminals, piracy is thus condemned as both a religious and secular crime. Mather is more than a religious preacher; he also fortifies and installs in his audience, which usually comprised between 550 and 850 people (Minnick 1968, 79 ), obedience to worldly laws as the "Justice of Heaven" (Mather 1704, 25 ) is brought about on the Boston execution dock.

What triggers Mather's most fervent rhetoric is the frequent laxness and merriment with which the pirates await death, descriptions of which can be read both as pirates' resistance to repentance and as a message to the reader about how not to behave before death. He tries to rationalize this attitude somewhat benevolently as "in their very Chains, [they] have been so stupefied, as to flatter themselves that there was no Danger near unto them; They have it may be spent their Time in Drinking, in Gaming, in Profane Frolicks" (13; my emphasis) in an act of repressing their guilty conscience (14). The Warnings follow the classical structure of the Puritan sermon (Cohen 1993, 7); the second part, an "Application" (Mather 1704, 25) of the biblical "text" (the introductory passage from the Bible) and Mather's "doctrine" (i.e., his thesis on sin) in the first part, includes quotations, examples, and anecdotes of historical cases 
of sinfulness and godly punishment to illustrate his admonitions. ${ }^{59}$ In yet another list of sins, Sabbath breaking, drunkenness, swearing and cursing (32), adultery (34), and thievery (36) are chosen because they are most closely associated with the seafaring life and piracy, itself listed as a subcategory of thievery. Mather's direct address ${ }^{60}$ of the pirates in the second part of the Warnings again reveals his astonishment upon the absence of fear of death and celestial punishment: "Be assured O Sinners, you have no Reason to be Merry or Easy, or Sleepy, in a state of Sin. You behave your selves, as if nothing were Amiss. What? When there is Evil pursuing of you!" (28-29).

\subsection{4 (Re-)Anglicization, Puritan Exceptionalism, Conversion}

Despite Mather's frequent focus on the exceptional role of New England as the world's foremost place of salvation, the framework within which he is preaching and writing is informed by a transatlantic culture of Puritanism, which can also be observed in Mather's continuing commentary on the persecutions in Europe or in his interest in German Pietism. The sensational execution sermon itself was adopted from English practice, but printed sermons, as Daniel Cohen asserts, seem to have been a genuinely American literary invention $(1993,3)$; furthermore, " $[\mathrm{t}]$ hat condemned criminals, whose behavior was hardly exemplary, were chosen to demonstrate the steps to salvation was a unique feature of New England Puritanism" (Williams 1986, 831), which attached more spiritual significance to the convicted, whose inner development in prison was closely observed. An exception to the standard practice of importing English literary genres and products, they gained rapid acceptance in America, especially among the Puritan ministers (Williams 1993b, xiii), and in fact made up, together with the religious confession and the criminal biography, the "first stage of narrative development of criminal literature in America" (Williams 1983, 8). This does not outweigh English influence, however, but rather renders the execution sermon a transatlantic genre (20). In Instructions to the Living, for instance, Mather quotes from older English Puritan clergymen like William Perkins of sixteenth-century Cambridge $(1717,35)$ and uses the case of a London execution of a thief and murderer in 1657, whose history was published as "The Penitent Murderer," to conclude the sermon (he quotes from its final section, in which eighteen ministers published their advice to the city and nation). 
This transatlantic continuity can be explained in two contexts, one of them being the need for what Harry Stout has called a "new mythology" at the turn of the seventeenth to the eighteenth century (1986, 118). The installment of the new charter in 1692, a consequence of the Glorious Revolution of 1688 that saw a crown-appointed royal governor, had provoked turmoil and factional division among the inhabitants of Massachusetts; a new explanation for the covenant was needed in order to counteract the dissolution of an earlier theocracy and provide social cohesion by other means, marking a paradigm shift in Puritan religious discourse:

According to the old orthodoxy, covenant keeping was not supposed to survive in an atmosphere of religious toleration [granted by the new government] and externally appointed magistrates. For over fifty years, ministers had routinely identified New England's covenant with an exclusive state-enforced orthodoxy. ... New England had become just one more appendage to a vast and sprawling imperial network. Why then were they still a peculiar people? (Stout 119)

Typical for many third generations of immigrants, Mather and his peers perceived themselves as far less isolated from Europe, but thrust into a larger Anglo-American world "where ... the faces of English institutions, customs, and officials would have to be recognized and reconciled to the original mission of New England" (123). This already points to the second, larger framework of Puritan transatlanticism in the eighteenth century: the oft-noted "Anglicization" of the American colonies as the political, economic, and cultural integration of the American colonies, most notably New England, into the imperial order after the Glorious Revolution. ${ }^{61}$ Thus, British patriotism and investment in English culture infused eighteenth-century New England (though, as Joseph Conforti argues, this shift is more accurately described by the term "re-Anglicization," 2006, 164):

To be sure, second-generation Puritan "creoles" had Americanized regional identity through the jeremiad and other epic, idealized historical accounts of New England's founding. In the eighteenth century, however, Puritan narratives of regional identity retraced New England's English origins. Inspired by the events surrounding the Glorious Revolution, Puritan descendants re-Anglicized the story of their ancestors' "errand" into the New World wilderness. The founders had come to New England in search 
of the English civil and religious liberty that the Glorious Revolution finally established in the homeland. (Conforti 2006, 164)

Like his Magnalia Christi Americana, Mather's pirate execution sermons are not only heavily influenced by these developments, but they themselves partake in this type of discursive patriotism. Mather's Instructions, for instance, repeatedly express the wish that God ensure the success of the British crown in the endeavor to extirpate piracy, praising the clemency of governor Shute (1717, 7-9) and the King's "Inflexible Justice that we see joined with a Temper full of Mercy" (19). Eventually, his praise of British anti-piracy measures, which he compares in his Instructions to Pompeius' destruction of Carthaginian and Corinthian piracy (3; the anticipation of British success is also apparent in the Instructions' caption title, "The End of Piracy"), can be read as an attempt to convince the population of the advantages British rule brings for New England. Using the neoclassical comparative fashioning of England as Rome, Mather emphasizes the urgency of the piratical threat when he describes how the pirates of antiquity interrupted all commerce, starved Rome, commanded 400 towns, and developed their own Commonwealth, including elected governors (4). Thus, with the help of anti-piratical rhetoric, Mather discursively consolidates English rule as a force of protection.

Within this transatlantic framework of Puritan society and its increasing Anglicization during the eighteenth century, the pirate was constructed as an Other both in terms of national allegiance to the imperial center and political legitimacy as well as in terms of cultural and religious difference, a discourse that would set the stage for future methods of Othering the pirate. At the same time, the discourse of New England exceptionalism does not disappear. On the one hand, piracy threatens the British Empire and must be besieged for that reason; on the other, piracy is more specifically a danger to the socioreligious integrity of New England, founded on a covenant with God that requires constant renewal efforts, and thus must be kept out of New Jerusalem. As Mather describes piracy as part of God's providential framework, "newly fallen out among our selves" $(1704,48)$, the implication is that the colony must have sinned to deserve this punishment. Within the same logic, successfully ridding New England of piracy would mean the restoration of the covenant with God. This is the reason for Mather to construct anti-piratical activities as requiring a collective effort and fervor of prosecution. Notably, he feminizes pirates as sinful, even perhaps satanic seducers of the young men of New England 
(in the following quote), thus recalling the Biblical convention of Adam and Eve; the American Adam is seduced to sinful, "piratical courses" that would lead to his (and, as pars pro toto, the settlers') expulsion from their New England Garden as God's punishment:

There has been a Time, when some have come and Seduced and Enchanted several of our Young Men, to Piratical Courses; and there were some Unhappy Advantages, which the Sinners took, to shelter themselves in the Prosecutions of their Piracies. But the Government of New-England will by a severe Procedure of Justice, forever make it an Unjust thing, to Reflect on the Countrey, as if such dangerous Criminals might hope ever to be safely Nested here. All the Serious and Sensible People in the Land, have a great Horror upon their minds, That when they see a Theef, there may be no Consenting one way or another with him. (46-47; my emphasis)

In an anonymous foreword to Mather's sermon The Converted Sinner (1724), ${ }^{62}$ success in England's increasingly vehement efforts to suppress piracy is contained within the same framework of New England's religious exceptionalism. The ardent prayers of the New England Puritans are thought to have had a direct relation to these successes: "We know of several Thousands, that in a little Time have Perished Wonderfully! And no where more Wonderfully than on the Coast of New-England, where the Prayers against them, have Distinguishing Ardours" (1724, n.p.).

Further, if pirates were seized and convicted, the Puritan congregation should strive to convert the sinners before their execution to purify both the pirate's soul and the New England conscience, which was increasingly ill at ease with the death penalty as the eighteenth century progressed (Minnick 1968, 86-88). ${ }^{63}$ The language of purification, where sin is poison and repentance "vomit" (Mather 1717, 28), is notable in many of these execution sermons. In this context of conversion, the analogy in the construction of pirates and 'Indian' heathens is striking. Pirates are repeatedly described as barbarous (sea-)monsters, and "Pradacious Animals" (4), repeating the contradiction between rhetorical dehumanization and conversion inherent in the colonial missionary effort ever since Columbus' first letter from the New World. Mather's sermons "shifted from indicting the community for welcoming illicit sea marauders in the 1690 s to pronouncing pirates as monstrous outsiders by the 1720 s" (Hanna 2015, 393). Subsequently, the monstrosity and inhumanity of pirates became a persistent racial trope that would reappear through at 
least two centuries, with gender and sexual deviance as additional layers of signification that texts about piracy could entertain (and entertain with).

In Mather's text, the chance at successful conversion, also important in the minister's efforts to "do good," turns barbarians and monsters, talked about in the third person, into "my friend[s]," who are now directly addressed (e.g., 10, 12). At the same time, caring for the souls of these "monsters" also proves the exceptional place of New England as the City upon the Hill, emphasizing the greatest humanity of the Puritans: "perhaps, there is not that Place upon the face of the Earth, where more pains are taken for the Spiritual and Eternal Good of Condemned Prisoners" (9). As not only the execution sermons show, the conversion of condemned pirates from atheism or from serving "Other Gods" like "Satan" (15) or gold and silver is of central importance for Mather. ${ }^{64}$

\subsubsection{Economies of Salvation}

Preparing for a sermon that was later profitably published in a run of 1,200 copies as Instructions to the Living, from the Condition of the Dead: A brief Relation of Remarkables in the Shipwreck of above one Hundred Pirates, ${ }^{65}$ Cotton Mather asks himself "[h]ow to render the Condition of the poor Pyrates, who are coming on their Trial, serviceable unto the Interests of Piety in the World" $(1957,481)$, and a few days after decides he will "entertain the Flock" by a "Discourse on the Folly, of getting Riches, and not by Right," thus turning to the ethics of Puritan economic behavior. Despite Calvinist doctrine, which holds that salvation cannot be accomplished by any kind of indulgences, the language of Mather's conversion efforts is often that of a barter for salvation as he casts the benevolence of God into a rhetoric of bargain, trying to market conversion to the pirates: "O Wonderful Call! Salvation to be had for a Look [to the Saviour]!” $(1717,21)$. Similarly, the pirates' economic transgressions are condemned within a religious framework, drawing on a Puritan ethics that denounces materialism and the desire for wealth while emphasizing fairness and restraint in all business relations: "You have placed on the Riches of this World, the Dependence you should have, had only on God," Mather argues in his Instructions $(1717,15)$, and in The Converted Sinner claims that "The Riches which are the Desire of all Nations, have nothing in them to be desired, if weigh'd in the Balances against the Riches, which your Turn to GOD will invest you with all!" $(1724,11)$. 
The necessity of virtue in one's economic strivings, noted by Werner Sombart and Max Weber in their explorations of the development of a protestant work ethic, is an important argument in Mather's condemnation of piracy. The Instructions suddenly end on page 39, when a new page header announces the second part of the sermon to be Warnings to Them that make Haste to Be Rich. The "sad Spectacle, a very black Tragedy" that is the "just Sentence of DEATH" for the pirates, is put into an economic context here: it is their "wicked Attempts to get Riches and not by Right" $(1717,40)$ that mark the pirates, like other thieves, as sinful. Yet Mather starts his propositions by saying that in less extreme forms, unrighteous economic strivings are a common sin of his time (43). Unlike in the rhetoric of monstrosity and inhumanity, piracy does not denote radical alterity in this economic context, but represents merely one form of transgression, an extreme in a continuum of breaching the eighth commandment. ${ }^{66}$ Notably, the late Louis XIV is invoked in a direct address as the greatest pirate of all, although other "Hero's" as well are condemned as robbers:

And here it may be complained, That while the Laws reach the lesser Pirates of Robbers, there are ... much Greater Ones, whom no Humane [sic] Laws presume to meddle withal: Monsters, whom we dignify with the Title of Hero's: Conquerors and Emperors, but yet no other than a more splendid sort of Highway-men. Of these, Many have done abominably; But thou, the Leviathan lately at Versailles, hast excelled them all. (44)

Harking back to the animosities between England and France and the many political and military conflicts between 1689 and 1713 that had also been played out in the New World, this is a highly interesting passage in Mather's sermon, for it uses a type of argumentation that pirates themselves have employed to their defense since antiquity. It also hints at piracy as a practice of vanguard nation-building and expansion, such as by the notorious Elizabethan privateers, legitimized often only after its accomplishment. When Mather quotes the first book of Corinth, 3, 21, "All things are yours" in The Converted Sinner, he uncannily echoes the utopian economic ethics of piracy, which basically claimed the equal distribution of the world's riches to all. Time and again, thus, one finds instances of overlapping discourses that are taken more literally and translated into worldly reality rather than relegated to the spiritual realm by piratical practice. The language of trade is a language spoken by the 
pirates as well as the Puritans and the general population, and comparisons between the "the merchandise of Silver" and "fine Gold" with the "Merchandise" of "the work of GOD" (21) seem to be so frequently deployed because it was a language that Mather's audience understood well.

Puritan riches in these sermons are of course of a radically different sort. Yet as Bernard Bailyn has demonstrated, the ideal Puritan standards for judging economic behavior in New England were largely confined to the first generation of merchants who "agreed that religious considerations were highly relevant to the conduct of trade, that commerce, required control by moral laws" $(1955,19)$. At the end of the seventeenth century, as a mercantilist colonial economy had been realized also with the help of the Navigation Acts and additional tariffs, wealth was flowing in mainly one transatlantic direction, and the New England economy struggled with the consequences (182). The suppression of piracy, together with "the tightening control of trade with the bullion-producing Spanish colonies, and a decade without war and privateering in the Atlantic world dried up other familiar sources of coin."

Pirates, on the rise again since 1713, were thus an important economic factor at least for parts of the New England population, as they were known for spending money freely in coastal towns. On a somewhat speculative note, pirates, like merchants, might even have contributed to the emergence of an empire of goods and a consumer revolution in the eighteenth century, as New Englanders were developing an appetite for imported products and became increasingly important as a market for the British Empire. As Conforti argues, the introduction of tighter trade regulations and the admiralty court system at the end of the seventeenth century "did not significantly hinder New England commerce, mainly because they were not consistently enforced" $(2006,174)$. Pirate ships scorned the mercantilist rule that did not allow any other than British ships in colonial ports and might have brought different and cheaper goods. Mark Peterson (1997), in his revision of the dominant narrative of New England Puritanism, which cast piety and prosperity as enemies, has taken one step further in arguing that worldly prosperity itself was integral to the sustenance of Puritan religious culture as well as the growth of New England, and these developments delivered a blow to the anti-commercialism of earlier generations. Peterson's arguments have been taken up by Michelle Burnham's study of colonial New England from the perspective of the world systems theory purported by 
Immanuel Wallerstein and others, Folded Selves: Colonial New England Writing in the World System (2007). By studying sermons and other literary works of colonial America, Burnham skillfully demonstrates that the old debate among scholars of Puritanism seeing Puritan society motivated either by religious or economic considerations is ahistorical (2007, 6 ); from the beginning, Puritan writing was invested with the language of the market and shows a profound interpenetration of economic and religious discourses that parallels the aesthetic debate between a plain style of writing - the Puritan ideal that allowed metaphors only if they were derived from the Bible-and more elaborate literary expression. As Burnham argues, the language used by and about dissenters folded economic anxieties; "Piety and Profit," the title of one of her subchapters, were deeply entangled issues and mutually sustained each other (12). In this, she follows Philip Gura's view of "the economic origins of the American self" (1986-1987, 256) exposing "an ideological investment in an American national narrative that wants to insist on the spiritual and communitarian rather than the material and commercial origins of the United States" (Burnham 2007, 11), especially if seen from a global perspective of world economics rather than within the nationalist trope of religious freedom. Moments of crisis in Puritan society, Folded Selves argues, betray an "extraordinary anxiety about commerce and hostility toward merchants and traders who are accused of misusing not just money but language - of lying, deceiving, and cheating," thus highlighting the complicated ambivalence about, discomfort with, and resistance to American capitalism that produce a "paradoxical discourse of uncertain certainty" (37).67

The anti-piratical sermons discussed here clearly betray the same entanglements and paradoxes. Judging from the increase of anti-piratical sermons after 1713, Puritan ministers like Mather seem to have felt that the increasing commercialism of New England threatened the moral integrity of their congregations and therefore appropriated the language of trade and exchange to ward off economic cooperation with pirates. The sermon form, "the sole form of legitimate public address" (Brown 1989, 34 ), was frequently used for such "ritual application[s] of theology to community-building and to the tasks and trials of everyday life," as Daniel Boorstin notes $(1958,12)$. Tackling an increasing commercialism, Mather explains the Puritan covenant with God itself in the language of trade as "A Contract or Compact" $(1724,27)$ in The Converted Sinner, and Jesus Christ is cast as a "Debtor to the Law for us" (42). The religious discourse 
of the anti-piracy sermon is thus not one of anti-commercialism, but instead attempts to remind New Englanders of their duties as commercial agents and subjects.

In the same vein, we can read Mather's construction of piracy as a result of idleness in his Useful Remarks: "They that would not behold the way of the Vineyards, nor take to any way of Honesty \& Industry, for Living ashore, have gone to make their Depredations on the Waters; But how has their Portion been Cursed in the Earth; and what a Remarkable Curse of GOD, has been upon them?" $(1723,22)^{68}$ Piracy, as the more sinful version of seafaring, is perceived as the economic opposite of honest labor, and the labor of sailors at sea the more sinful version of work in the biblical vineyard, a metaphor for work ashore. ${ }^{69}$ Rather than seeing piracy as the expression of resistance to the widespread abuse of sailors by maritime authority and the mercantilist system of profit and gain, it is defined by its accumulative ethics of exploitation. Interestingly, Mather would acknowledge the dimension of abuse a few years later in his account of the famous case of William Fly, after his attempt at Fly's conversion had utterly failed.

\subsection{6 "The Complicated Plot of Piracy": Hybridization, Resistance, Counterpoints ${ }^{70}$}

Mather's instructions for prayer and repentance in question-and-answer sections appended to the sermons, often containing an assessment of the repentant's sincerity $(1717,9-34)$, introduce a dialogism to the genre of the execution sermon that was fundamental for the development of the popular literature of crime, as it was, according to Mikhail Bakhtin, for the novel (cf. also Davidson, who explains that the novels in the early Republic "assayed the social terrain of beggar maids, the rural poor, illiterate immigrants ..., prostitutes, pirates," 2004, 28). As sermons generally experienced a shift "from religious indoctrination to quasi-journalistic crime coverage" (Cohen 1993, 9) and from a language of spirituality to a rhetoric of adventure, sensation, and heroization in the early eighteenth century, they anticipated and nourished a significant development in early American literature. ${ }^{71}$

However heavily Mather may have edited the pirates' answers, which in the beginning amount to only a small percentage in length compared to the minister's admonitions, these dialogic sections usually leave traces of doubt and uncertainty on the pirates' side that are detectable in the 
printed texts. While some of the condemned cry out for God's mercy, others express their conviction that they "can do nothing!" $(1717,13)$, repeatedly answer Mather's questions by "I hope I do" (15-16) rather than by "I do," or reply that they "can't well tell, what to say to it?" (34); Mather's answers likewise demonstrate insecurity about how seriously the pirates are to be taken in their repentance. Others try to defend themselves up to their last minutes of life, arguing that they were "Forced Men" (17) despite all the contrary evidence Mather lists, or own that their hearts are still "grow[ing] harder" (20) while Mather repeatedly emphasizes the importance of a softened heart for salvation (24). Despite the fact that Mather's version of heavenly mercy is at times very lenient ("Our Good GOD is One who takes pleasure in them that hope in His Mercy," 11), these hesitations appear as traces of resistance to Puritan doctrine and show a great imbalance between Mather's lengthy affective efforts at conversion and their actual effects.

Another tension in the Puritan execution sermon is to be seen in the contradiction between providence and agency, between the doctrine of predestination (relaxing gradually only after 1740) and the appeal to one's free will and choice (Minnick 1968, 82). Repeatedly, Mather exhorts condemned pirates to turn their hearts to God, to repent and pray for conversion, while at the same time arguing that "you cannot Change your own Heart!" $(1724,36)$ and constructing seafarers in general and pirates in particular as a cursed collective. ${ }^{72}$ This contradiction did not go unnoticed by the pirates, as the printed conversations between Mather and the convicts demonstrate. "We thought we could," one of the pirates answers to Mather's call (37), adding a few pages later, toward the end of their conversation, that they "know not what to do" (42) and that "we have understood nothing of it!" (46)—even after all the instructions Mather has given them. Mather ends The Converted Sinner, a sermon entirely based on the demonstration of the pirates' sinfulness and its dire consequences, by stating that "these Poor Men may after all, be found among the Elect of GOD" (49), a closure containing a message that is the exact opposite of Mather's aim to convince the sinners of the need for conversion. This cannot but have been utterly confusing for sailors and pirates who were not well-versed in Calvinist theology and certainly not among the regular attendants of Puritan services. More than this, it could lead to resistance among the sinners.

Both Daniel Cohen (1993, 67-68) and Daniel Williams (1987) have elaborated on the case of William Fly, a pirate captain who refused to 
repent, taunted his hangmen at his execution, and led Mather to publish The Vial poured out upon the Sea. A Remarkable Relation Of certain Pirates Brought unto a Tragical and Untimely End (1726). This publication is a case in point regarding the development of the sermon toward sensationalism briefly outlined above, as it shows how

[s]pecial expedients were resorted to, designed to make the published sermon further appealing. Title pages were sometimes bordered in black with a skull in the center of the page, flanked on either side with crossed shin-bones. Certain key words were set in bold type in the title; e.g. SODOMY, MURDER, BEGOTTEN IN WHOREDOM, PIRACY, RAPE; titillating adjectives were employed. (Minnick 1968, 80)

The title page of Mather's Vial prints "PIRATES" in capital letters and boldface, and only a few lines later the word "SERMON" appears, also in bold, but somewhat smaller; a similar change is noticeable three years earlier in the Useful Remarks, which boasts of the "Pirate Speeches, Letters, and Actions described" it would offer. ${ }^{73}$ Intertextual relations with other, more documentary genres of the emerging literature of crime and adventure thus became increasingly important.

One example of the sermon's hybridization is the partial use of a crime ballad by the English poet Richard Blackmore for the very beginning of Mather's Vial, certainly a concession to his audience, as Mather himself was opposed to any entertaining popular literary forms and Blackmore was an object of satire rather than a respected poet in his days. The choice might also hint at Mather's recognition of the fact that ballads were among the most accessible forms of literature, designed to be memorized and repeated; it could be known by all parts of the population, notwithstanding illiteracy (Burgess 2014, 80). What follows is first a factual, somewhat adventurous account of Fly's piracies that approaches the style of criminal biography (famously used by Captain Charles Johnson's report of the case in the second volume of the General History of the Pyrates of 1728, the source for many future adventure stories of piracy across the Atlantic world). ${ }^{74}$ The next parts are two "Conference[s]" between Mather and the convicts, so that the actual sermon does not start before page 28 and ends on page 47 , where another new element is introduced: a sensationalist description of "The Execution," reporting the pirates' behavior. This incorporation constitutes an instance of adapting literary forms to the desires of increasingly sensation-hungry audiences in 
order to seize their tastes for Puritan ends; as Daniel Cohen avows, "one man's providence is another's sensation" (1993, 10), and some of the quasi-journalistic histories attached to sermons by Cotton Mather had no distinct spiritual significance in themselves. As the sermonic part of the publication began to decrease in popularity and readers might have focused on the more sensational parts of these works, its textual politics became one of greater complexity and mixed messages.

Already on the very first page of the biographical section ("A Remarkable Relation of a Cockatrice crush'd in the Egg"), piracy is explained as "a way of Revenge, they said, for Bad Usage" (Mather 1726b, 1); in the "Conference with the Pirates," the second part of the book, the narrative distance of indirect speech disappears as we read Mather's dialogue with the pirates in direct speech. Mather starts by exhorting them that they "must not think how to brave it out so sottishly and hardily, as I am told, some of you have made some Essay to do" (7), hinting at what was considered blasphemy by the Puritans. Benjamin Colman, the renowned Boston pastor, published an equally hybrid sermon-account of the Fly case and cites as evidence for Fly's blasphemy that "he wou'd sometimes even dare to ridicule the nose of Gods Thunder, as it rattled over him, Saying, That they were playing bowls in the Air, \&c. and as the Lightnings sometimes slash'd upon them, he would say-Who fires now? Stand by, \&c.- So he dar'd the dreadful Vengeance, which persu'd him swift as the Lightnings and suddenly struck him" (36). In Fly's first actual appearance on the next page, he denies the murder he is convicted of, which Mather in the following insists is a lie. The minister is confounded:

M. Fly, I am astonished at your stupidity. I cannot understand you. I am sure, you don't understand yourself. I shall be better able, another time to reason with you.

Fly said, It is very strange another should know more of me, than I do of myself. There are False Oathes ta[ken] against me. (9)

As little as Mather can understand Fly's stubbornness, Colman can relate to the hardships of life at sea. The terrifying confrontation with elementary forces such as thunderstorms induces in Fly a sense of humor that was perhaps a matter of everyday survival, of coming to terms with the dangers at sea; the Puritan understanding reduces it to blasphemy, judging it by standards hardly applicable to life at sea. 
Mather and Colman, the harsher judge of the two, both emphasize Fly's relentless self-defense and his disinterest edness in repentance (Colman calls Fly's behavior in prison the "greatest Instance of obduracy that has yet been seen," 1726b, 38). Fly's is not a singular case in this respect; Mather's Instructions relate the behavior of convict John Brown at the gallows, which is described "at such a rate, as one would hardly imagine that any Compos Mentis, could have done so. He broke out into furious Expressions, which had in them too much of the Language he had been used unto" $(1717,37)$. After a blank gap in the printed text that hints at the blasphemy that Mather refuses to reproduce (and therefore relegates to his readers' imagination), Brown "fell to Reading of Prayers, not very pertinently chosen"; Mather comments: "In such amazing Terms did he make his Exit! With such Madness, Go to the Dead!" (38). ${ }^{75}$

Daniel Williams implies a continuity between piracy and the American struggle for democracy and independence in his discussion of the Fly-Mather case on the grounds that pirate crews turned their ships into experimental, if unsustainable and short-lived sites of an alternative social order based on proto-democratic values like fraternity, justice, or equality at least among themselves $(1987,247)$. The historical character of William Fly is thus interpreted by Williams as a vanguard in his resistance against oppression, as Fly justifies his crimes as the appropriate response to a captain and a mate who had used him "Barbarously," claiming that "we poor Men can't have Justice done us" (Mather 1726b, $21)$ otherwise. Unintentionally, it is the publication of the sermons themselves that passed on the piratical counter-perspective to contemporary readers as counterpoints in the texts. As Fly himself boasts that he has already read Mather's Converted Sinner when the minister, at a point of despair in his efforts to convert Fly, offers to bring him the pamphlet, one might even speculate about Fly's intentional use of Mather's text to defend himself in front of a wider audience (17).

Indeed, the conversations between Mather and the convicts in these publications give us numerous instances of self-defense, an oppositional gesture that haunts the pirates' display of repentance even within a single text. While one consistent line of argumentation employed by the convict was that he was a "forc'd man," an argument that could save him from the gallows if he was able to prove it, 76 "bad usage" is most frequently invoked as the reason for mutiny, piracy, and the use of violence: Colman concludes his publication with the alleged last words and letters of the 
convicts, some of who "said little, but warn'd all Masters and Commanders, against severity and barbarity to their Men, which (they said) they were persuaded is the reason of so many turning Pirates" (39). What is at stake in representing unrepentant pirates in this way is the potential creation of solidarity among those strata of the New England populace that experienced similar ways of mistreatment and oppression. The pirate would thus not appear as an Other to them, but rather as a social rebel and a radical agent of resistance. In the later context of the American Revolution, this discourse of oppression and piratical resistance would shift to bear anti-colonial and national ramifications rather than social ones.

In Mather's Vial, Fly turns the minister's religious ethics on its head when he says he cannot forgive his former commander for his harsh treatment: "It is a Vain Thing to ly, If I should say, that I forgive that Man, and that I wish him well, I should ly against my Conscience, and add Sin to Sin" (16); "God reward them according to their Deserts" (20). It seems that Fly's argumentation did not leave Mather unaffected. At the end of the pamphlet, in a report of the actual execution, Mather surprisingly pays homage to Fly's reasoning despite of his former anger. From addressing "poor Sailours" (44), Mather suddenly turns to their masters:

I would presume upon an Address to the Masters of our Vessels, that they would not be too like the Devil, in their Barbarous Usage of the Men that are under them, and lay them under Temptations to do Desperate Things. We allow, Syrs, That you must be Commanders aboard, and you must keep a strict hand over your Men; and you may, as Times go, too often have occasions for Severities; But still, there must be no room for Barbarities ... The Men must be used as Rational Creatures. ... They are your Brethren. (44-45)

Though Mather might have incorporated this critique of maritime authority in order to contain Fly's criticism within his own narrative framing, seeking to control the public perception of the pirate when he could not control Fly himself (Williams 1987, 238), it is indeed questionable "who was really calling the ideological tune" (Cohen 1993, 68) in such instances of two-way appropriation.

Ideological controversy is detectable also in the discourse of class, Mather calling Fly an "upstart Captain" (1726b, 5) while Fly refers to himself and the crew as "Gentlemen of Fortune" (2), purporting to 
have freed himself from in-born class hierarchies (Williams 1987, 247). Fly used the term to formulate a new self-description, demonstrating his belief to have transgressed class barriers. From above, the threat the pirates signified was perceived as directly related to social mobility and discontent with one's class position, obvious in Cotton Mather's use of the exhortation to "stay in your place contentedly."

Resistance could take many creative forms, even within the limited range of action available to Fly and his fellow convicts: the refusal of religious services offered, inattentiveness, gestures of ridicule at court or in church (Minnick 1968, 85), or recalcitrance and understatement in the conversations with the ministers. This does not go unheeded in the narrative attempt at containing piracy: when Mather asks for a full confession as a step toward salvation in his Instructions, for instance, Simon Vanvoorst, a convicted Dutch-American pirate, replies with "Undutifulness unto my Parents; And my Profanation of the Sabbath," which leaves the minister dissatisfied as he wishes "that you, and all your miserable Companions here, were more sensible of the Crime, for which you are presently to be chased from among the Living," that is, piracy and murder $(1717,16-$ 17); Mather's increasing impatience with such recalcitrance is represented by the use of numerous dashes, gaps, italics, and exclamation marks in the printed conversations.

Similar counterpoints can be found in the first section. By avowing to stick to the facts, the text mentions that pirates were not entirely merciless, releasing captives that did not represent a threat $(1726 \mathrm{~b}, 3)$ and that their cruelty was born out of the necessity to defend and protect themselves from their enemies. Atkinson, a captive whom Fly kept because of his skills as a pilot, promises to take them to Martha's Vineyard, but "purposely miss'd the port, (whereat Fly was very angry)"; the captives incite a mutiny and "made themselves Masters of the Snoe" in an act similar to how the pirates had taken the ship. "On June 28. the Happy Captors brought in their New Captives, having taken them Captives, whose Captives they were" (5): if we presume that at least part of Mather's readership was potentially sympathetic or indifferent to the pirates that bolstered the economy of coastal towns in New England and were an attractive alternative for many sailors, ${ }^{77}$ one can conclude that the main effect of passages like these is delight and entertainment rather than anti-piratical sentiment. 
Of course, Mather himself displayed nothing but Puritan distaste for popular entertainment; in his instructive sermons, for instance, he advises young people to shun playbooks $(1717,48)$ and condemns the rough oral culture of the ship (e.g., Mather 1704). Though Mather's authority was by no means premised on the observance of his elite status, the minister's aversion to lower-class verbal expression also betrays his class privilege as he critiques the blasphemy of "Vain Thoughts," "Ears ... more delighted with Scurrility than with Spirituality," and "a Mouth full of Rotten Communication" $(1704,26)$. Ironically, however, the minister sometimes makes use of the popular oral form of the tall tale as anecdotes of godly intervention for the sake of justice (e.g., when he relates how a "horrid fellow aboard a Ship" who was "belching out his Affronts to Heaven, and Swearing \& Cursing at a most hideous rate" was struck with a God-sent flash of lightning that "pierced his tongue," 33-34). As Wayne Minnick asserted, the use of such anecdotes is highly unusual in Mather's other writings, as the minister "considered it criminal to demand more confirmation than the Word" (1968, 83). Accordingly, Mather spoke about his choice in an apologetic manner, implying that a convention against such material existed among the ministry, and justified his use of such tales by saying they were appropriate for the occasion $(1704,41)$. Minnick concludes that "[p]erhaps because he was preaching on this occasion to three pirates who, from indications in the text were not greatly impressed, Mather felt impelled to use this unusual kind of anecdotal proof" $(1968,83)$.

While the use of sensationalist elements certainly ensured a continuous readership for the Puritan execution sermon, Mather's choice also backfired, gradually lessening the attractiveness of the religious discourse used in the sermons and increasing sensationalist desires in his readers. This contradiction - the need to attract a larger audience on the one hand and the Puritan aversion against entertainment on the other-turns into irony considering the fact that the execution sermon itself was the most popular form of crime literature around the turn of the seventeenth to the eighteenth century. ${ }^{78}$ What is more, the effects of the traces of piratical resistance that run as main threads through these sermons were certainly unintended, as they played into the hands of the equivocal attitude of an audience that was not necessarily on the side of the authority, as Michel Foucault argued in his study of "The Spectacle of the Scaffold" in Discipline and Punish ([1977] 1995, 65-67). 


\subsubsection{The Gallows Literature of Piracy: "Let Not the Lust of the Eye Poison o Pervert You!”}

In his analysis of sea deliverance in Mather's Magnalia Christi Americana, Udo Hebel interprets the increasing concern for verisimilitude in Mather's writing as a recognition of pleasure and as an important category for reading $(2004,26-27)$. Entertainment by sensation (cannibals, sea-monsters) and seriality (as repetition and variation) entered the New England literary landscape, pointing ahead "to the more secular narratives ... that would become part of American popular culture throughout the eighteenth and into the nineteenth century" until "the transcontinental journey challenged the nature of American culture as a maritime culture and modif[ied] the role of the sea as the favorite frontier in American literature" (29). The process of Anglicization that New England underwent in the early eighteenth century also led, as Sara Crosby states, to the release of printers from religious censorship, enabling them to compose cheap "gallows literature" $(2010,8)$ like one-page broadsides that presented "authentic" (auto-)biographies of convicted pirates, final words and confessions, ballads, and eventually lengthier criminal histories- "genres which characterized England's popular street literature" and constituted a profitable business (Burgess 2014, 226).

The spectacular nature of the executions themselves geared their accompanying literary representations toward this sensationalism. Like the religious services during which clergymen delivered their sermons, the public hangings aroused much popular interest in early New England, as crowds often amounted to thousands of people who either lived in or traveled to the coastal towns in which the hangings were to take place (Cohen 1993, 3). In the words of Mark Hanna, "New England executions were typically orchestrated as communal, cathartic experiences where criminals admitted guilt, sought forgiveness, and warned witnesses to avoid the trade winds to perdition that swept away men seeking their fortune" $(2015,332)$. The spectacle itself was thus set up with explicit intentions by the establishment: "The Glorious GOD Expects, that we do the best we can, to make this a Profitable \& a Serviceable Spectacle; and that our Foolhardy Sinners, Knowing the Terror of the Lord, may be Disswaded from going on still in their Tresspasses" (Mather 1723, 20).

Drawing on Foucault, the sensationalist aspects of both the execution itself (which Hanna calls a "ritual of terror," 2015, 331) and its representation in the literature of crime, of piratical terror answered by 
the "terror" of God $(22$; see also Colman 1726, 19) and a state acting as God's hangman, serve an important function in the consolidation of existing hierarchies. Foucault argues that such spectacles speak a language of excess that goes beyond the mere redress of a crime ([1977] 1995, $48)$; it is a "spectacle not of measure, but of imbalance" (49) that worked through the presence of the criminal and represented a "policy of terror: to make everyone aware, through the body of the criminal, of the unrestrained presence of the sovereign." In the context of early New England, the presence of the condemned sinner in church (where the execution sermon was usually preached) was of utmost importance and heightened the sensationalism of pirate executions. If the sermon was preached on execution day, all adjourned from the house of worship and trooped to the scaffold, with the minister accompanying the condemned man, conversing and praying; the multitude, up to 12,000 people that had come from all areas for the special occasion, frequently disturbed these conversations by wanting to be as near to the prisoner as possible (Minnick 1968, 79-80).

Accordingly, Captain William Fly's refusal to appear in public when Mather preached the execution sermon must be read as a resort to his own agency as someone who was already judged a dead man by the ministers, an act of resistance to participate in the spectacle of his own hanging at a point in which he had "nothing more to Expect from the World," as Fly puts it in the first conversation with Mather (1726, 15). During his time in prison, Fly goes on hunger strike and "declined appearing in the Public Assemblies ... because, forsooth, he would not have the Mob to gaze upon him" (47); on the day of his execution, however, he adopts an entirely different strategy, fashioning himself after the heroism of English highwaymen and robbers he might have heard of through the transatlantic circulation of popular crime ballads and songs (Cohen 1993, 67-68). Mather reports how Fly manages to use the spectacle of the execution to his own ends, asserting the agency of a condemned man who had nothing to lose, bonding with members of the crowd, and putting on a performance of scorning death despite of his fear. Fly "concentrated on preserving his independence of mind by denying the significance of death and damnation" (Williams 1987, 234); as Mather reports, the pirate

... seem'd all along ambitious to have it said, That he died a brave fellow! He pass'd along to the place of Execution, with a Nosegay in his hand, and making his Complements, where he thought he saw occasion. Arriving 
there, he nimbly mounted the Stage, and would fain have put on a Smiling Aspect. He reproached the Hangman, for not understanding his Trade, and with his own Hands rectified matters, to render all things more Convenient and Effectual. When he was called upon, to Speak what he should judge proper to be spoken on that sad occasion, at least for the Warning of Survivers, he only said, That he would advise the masters of Vessels to carry it well to their Men, lest they should be put upon doing as he had done. (1726b, 47-48)

While the presence of the prisoner's body set the most convincing example according to the Puritan officials, the crowd, according to Foucault, was an even more important element in the semiotics of the execution. Their "real and immediate presence was required for the performance" ([1977] 1985, 57) in order to legitimize capital punishment, but the role of the people as spectators and interpreters of execution spectacles was ambiguous, as the carnivalesque dimension of the ritual bore the risk of the people turning the convict into a hero if he mocked authority. There was a reason to Mather's emphatic attempt at directing the reaction of the crowd to the execution spectacle into the desired direction: "Hear, Hear the Cry from the horrible Scaffold unto you. Oh! Let not the Lust of the Eye poison o pervert you!" $(1723,23)$. Mather was less concerned, perhaps, about the pirates' lost souls than about the souls of his congregation, which was more than once reluctant "to fully endorse both the trial and execution" (Hanna 2015, 343). In sum,

$[t]$ he gallows was a symbol of order, and those who mounted it were there to legitimize the power of those who erected it. Public executions, then, were one of the most important colonial contact points between the elite and the non-elite, between the ministers and the magistrates on one side and "the Mob" on the other. Paradoxically, however, by trying to control "the Mob" through ritual and convention, the authorities actually created popular expectations that ran counter to their attempts at subordination. By presenting large numbers of people with spectacles that both titillated and inculcated, they empowered the people they were trying to control by indirectly promoting a popular demand for sensation. (Williams 1993a, 11)

The popular literature of crime, most notably the execution sermon, played an important role in this spectacle, reaching beyond the mere 
attempt by Puritan ministers to draw a large audience by distributing their writings in cheap or even free pamphlet form (Cohen 1993, 4-5). Their frequent admonition to respect one's parents demanded respect for authority as such; the pamphlets, books, and broadsheets functioned as testimony and authentication. Yet this is only one side of the coin:

The effect, like the use, of this literature was equivocal. The condemned man found himself transformed into a hero by the sheer extent of his widely advertised crimes, and sometimes the affirmation of his belated repentance. Against the law, against the rich, the powerful, the magistrates, the constabulary or the watch, against taxes and their collectors, he appeared to have waged a struggle with which one all too easily identified. The proclamation of these crimes blew up to epic proportions the tiny struggle ... . [T] he criminal of the broadsheets, pamphlets, almanacs and adventure stories brought with him, beneath the apparent morality of the example not to be followed, a whole memory of struggles and confrontations .... . (Foucault [1977] 1995, 67)

Perhaps, then, Foucault concludes, we should see the literature of crime, which proliferated around the figure of the pirate in Puritan New England, as a two-sided discourse: "neither as a spontaneous form of 'popular expression,' nor as a concerted programme of propaganda and moralization from above; it was a locus in which two investments of penal practice met - a sort of battleground around the crime, its punishment and its memory." Execution sermons connected the audience and the criminal in sympathy, and with the decline of ministerial influence, these theological narratives increasingly ceded control over their 'message' (Crosby 2010,9). The fact that the anti-piratical sermon, which from the beginning incorporated sensational elements, progressively shed its religious frame in favor of this sensationalism is in itself not a unique characteristic of the Puritan discourse about piracy. Rather, the figure of the pirate used by Mather and the Puritans is symptomatic in that it marks the intrusion not only of secular values and the verisimilitudian "factualism" (Hebel 2004, 24) that resulted from English empiricist influence, but also of economic discourse as a cultural force into Puritan writing. Only when New England society drifted away from congregationalism and toward a democratization of belief and government, the public execution sermon gradually ceased to be a viable mode of public discourse (Minnick 1968, 89), although the genre itself continued to exist at least until end of the eighteenth century (Bosco 1978, 174-76). Its popularity 
certainly decreased; but he counterpoints, tensions, and contradictions of the Puritan anti-piracy sermon had paved the way for the aesthetic rewriting of piracy in the later eighteenth and nineteenth centuries, when the figure of the pirate was further turned into a heroic spectacle and a romantic version of rebellion at sea. Thus, there are more threads of continuity than discursive breaks between Puritan representations of piracy and its popular eighteenth- and nineteenth-century successors.

\section{Notes}

1. The "West Indies" are defined by Krise for the period under scrutiny as "an amalgam of confused and conflicted knowledge and desire" (1999, 1), while "Caribbean" has been used as a more inclusive geographical term, referring not only to the islands of the Caribbean Atlantic but also to the surrounding coastal regions (as they present a cultural continuum with the islands and belong to the same maritime world).

2. Edwards $(1994,5)$ and Craciun $(2013,171)$ refer to Dampier as the founder of the tradition of modern exploration writing in English, disregarding his less famous predecessors in this claim.

3 . For a brief overview of the history of buccaneering in the Darién region, see e.g. Muth (2011); for a brilliant critical anthropological study of the relations between European colonialisms and the Darién Kuna, see Taussig (1993).

4. "Marked by that 'crisis of European consciousness' of which Paul Hazard has spoken" (my translation).

5. On the American isthmus as a conflicted early modern scientific contact zone, see Mackenthun (2013).

6. For a discussion of piracy as either an Atlantic counter- or subculture, see Mackie $(2009,130-31)$.

7. The early modern genre of chorography has been discussed by Barbara Shapiro (1983) as a combination of scientific writing and social history, which, in Exquemelin, equals the interweaving of natural history and sensational pirate historiography (see also Frohock 2010b, 58-59). Edwards emphasizes the collective authorship of Dampier's and similar narratives $(1994,9)$.

8. The Black Legend refers to historical writing that demonizes and thus disqualifies the Spanish Empire in its colonial authority and legitimacy; the term was coined by Julián Juderías in his 1914 book La leyenda negra y la verdad histórica.

9. Motohashi's (1999) observations relate to his discussion of cannibalism, which he sees as the most extreme sign used in this discourse. 
10. On continuities between the picaresque traveler and the pirate in the popular literature of the early eighteenth century, see Richetti ([1969] 1992, esp. 60-118) and Ralph Bauer's reading of Carlos de Sigüenza y Góngora's captivity narrative in the Cultural Geography of Early American Literatures (2003).

11. On parallels between pirate and creole resistance, see Pérotin-Dumon (1991, 204).

12. Cf. Bauer $(2003,3)$; piracy as a semantic marker of crisis is indirectly linked here with the piracy of knowledge and data before institutionalized copyright. For struggles regarding the authorization of translations in the case of Exquemelin's text, see Arnold (2007).

13. In this context, Ralph Bauer emphasizes the diverging histories of Europe and colonial America in the development of their literatures as "uneven and co-dependent literary evolutions" (2003, 11). Both Irving and Bauer position their work in an Atlantic framework.

14. For a gender-critical reading of seventeenth- and eighteenth-century piracy, see e.g. Mackie (2009, 114-48), Karremann (2011), or the controversial monograph Rum, Sodomy and the Lash (1999) by Hans Turley. On matelotage, see also Rennie $(2013,18)$.

15. For a detailed history of the buccaneers, see Latimer (2009). The subtitle How Piracy Forged an Empire points to the fact that Latimer reads the buccaneers as a central force in the making of the British Empire.

16. "Raubmenschen ... die sich auf den erlegten Stier stürzten und ihm das noch lebenswarme Mark aus den Knochen sogen, die das Fleisch, ihre einzige Nahrung, zur Not auch roh verschlangen, die ihre menschlichen Opfer auf das grausamste folterten" in the German original; my translation.

17. Historical sources of such pirate articles have been recorded for the early eighteenth century; for reprints, see Antony (2007). Exquemelin explains Morgan's articles on p. 172.

18. Cf. David Armitage's criticism that "Linebaugh and Rediker do not inquire whether interracial alliances across the lines of status, craft, or freedom were exceptional when they did occur or whether they always did so in the context of opposition rather than acquiescence. Their portrait of the pirate-ship's 'multicultural, multiracial, multinational social order' (162) in the early eighteenth century cannot be reconciled with the picture that emerges from work on more typical and enduring maritime communities that has stressed the resilience of racial barriers and the exquisite hierarchies of status that persisted even far offshore" (2001, 484). Armitage takes issue with the easy opposition of hydrarchy from above and from below in this context, arguing that interracial solidarity was a product at least as much of cultural contact within the Royal Navy 
and the Army as of the pirate ship (485). See also Bolster (1997, 69; 90-91).

19. For a discussion of the French version, see Ouellet $(2004,53-56)$.

20. On Exquemelin's complex biography, see Beeching $(2000,18-19)$ and Arnold (2007, 10).

21. Exquemelin refers to a number of nautical terms, plant names, dishes, drinks, and material objects adopted by the buccaneer communities from the indigenous populations and partly Anglicized, such as maby (a drink), chicha (a fermented alcoholic beverage), tobacco, aloe, banana, cashew nuts, oranges, cacao or chocolate, manioc, pineapples, potatoes, hammocks, canoes etc. Sociolinguist Eva de Lourdes Edwards has read the book as evidence that the "multi-language, bi-directional maritime linguistic voyage and exchange" took place within only two generations: there is so little explanation of Amerindian words in the Buccaneers because "European languages had already been creolized" $(2007,621)$. Cattle was in fact foreign to the Taínos "as boucan was to the Europeans" but "the foreign elements were intertwined in [sic] both sides of the Atlantic" (627). The sociolinguistic upheaval in the book, in de Lourdes Edwards' view, is emblematic of the psychological and biological "chaos" produced by "the clash of two halves of our planet" (629).

22. The choice of an edition for study is a difficult one. It depends on research interest whether the first edition in Dutch is preferable to the most influential and popular editions of the time, which were translated into English by way of the Spanish (!) version. I have consulted the Dutch 'original,' the 1679 Nuremberg edition in German, and various English versions (which turn the author's name into John Esquemeling), and decided to use the modern English translation based on the Dutch version (1969) in this chapter because my interest is less in translation than the broader view of the literature of piracy as articulating and negotiating the epistemological crisis spurred by colonial contact scenarios in the Americas. For a comparison of various editions and translations, see Ouellet (2004), de Lourdes Edwards (2007), and Arnold (2007), who demonstrates the ways in which "[e]ach national tradition has positioned Exquemelin's book within its own socio-historical perspective" (9).

23. See also Jason Payton's argument that traditional early American Studies have made little room for "oceanic subjects whose modes of belonging and patterns of movement do not fit neatly within nationalist paradigms" $(2013,337)$.

24. The secondary literature on Exquemelin generally ignores the fact that he remains a servant when he joins the buccaneers (e.g., Linebaugh and Rediker 2000, 158). 
25. On the multiplicity of narrative points of view constructed in colonial histories and travel accounts, see Hartog (1988, ch. 6 and 7, esp. 258; 283-94).

26. This also has to do with Exquemelin's fate after returning to Europe and the history of the text; after the publication of the Spanish translation in Amsterdam, the grandee Don Gabriel Fernández y Villalobos had successfully intervened to expel both Exquemelin and the Spanish translator, also a medical doctor, from the Netherlands; "[a]gainst their will the two graduate surgeons were off again to 'America"' (Arnold 2007, 16).

27. See also Exquemelin's report of an indentured servant in the service of the buccaneers who runs away and gets lost in the woods: "He became used to eating raw flesh, and desired no other sort" ([1678] 1969, 56). When, after fourteen months in the wilderness, he comes across a group of hunters, "he looked utterly wild. In all that time he had not shaved, and he was completely naked apart from a strip of tree-bark which covered his loins, and he had a piece of raw flesh dangling at his side." Even after some time back with his group, he would not be able to digest cooked meat despite the fact that Exquemelin and his fellows "tried to keep raw flesh from him" (57). This episode reverberates with the dichotomy of "the raw and the cooked" (as the sign of civilization) famously explored by Claude Lévi-Strauss (1966).

28. Ayres' account of Captain Sharp's piracies calls the Protestant adventure a "Maritime Pilgrimage" (1684, 114).

29. Latimer mentions that Crooke made an insert in the second edition and wrote a groveling pamphlet, while the second publisher, Malthus, resisted and spread even "more malicious propaganda to generate publicity for his edition” (2009, 256), but Frohock corrects this version of the Morgan dispute, demonstrating that amended editions preceded the libel lawsuit (2010a, 507).

30. Much of this dialogue also continues in new English editions and reprints of The Buccaneers, partly with added parts and prefaces, as Frohock summarizes: "William Crooke published a second edition ... in 1684; a rival translation ... was printed by Thomas Malthus in 1684; Philip Ayres, The Voyages and Adventures of Capt. Barth. Sharp (London, 1684), includes a defense of Morgan's voyage and an attack on Crooke's translation, to which Crooke responded in the introduction to Ringrose ..." (2004, 72 n. 22).

31. William Paterson drew on Dampier and Wafer in forming a company to promote the Scottish Darién colony New Caledonia (1699); Wafer himself was questioned in Edinburgh under the promise of a commission for another expedition. Both Dampier and Wafer were called to the Lords 
of Trade and Plantations in London, who "were deeply hostile to Scottish colonial initiatives" (Edwards 1994, 35).

32. The earlier text was published by Philip Ayres, together with four additional travel and adventure narratives in this publication. Ringrose's account is presented as an anonymous journal "writ by a Seaman," "the first that came to my [i.e., Ayres'] Hands" (1685, n.p./A3). On Ringrose's authorship, see Joyce (1934, xxviii).

33. Under William II, this law allowed pirates to be tried anywhere in His Majesty's reign and introduced extended death penalties also to accessory pirates; the earlier mandatory return to London for trial had severely complicated and limited the execution of anti-piracy laws. Vice-admiralty courts were established in the colonies, which would lose their charters if they did not co-operate, as e.g. New York's merchant community (protesting the actions of their new governor, the Earl of Bellomont; see Thomson 1994, 50-51).

34. Ringrose's scientific ambitions culminated in his South Sea Waggoner of about 1682, an atlas of charts and sailing directions, based on Spanish documents captured by Ringrose, which the buccaneers used for their navigation of the Pacific coasts of America in its English translation; more influential than the Waggoner, however, were the harbor plans in The Dangerous Voyage, which were reprinted several times until 1771 (Howse and Thrower 1992, 32).

35. See also James Arnold's discussion of the frontispiece of the first French edition, which represents the two versions of colonialism; in the upper half - the Protestant version-all references to violence are erased and America appears as a pastoral, harmonious landscape in which an 'Indian' queen is revered by Protestant figures. The lower half, in contrast, shows two scenes of slaying, one with a Spaniard killing an indigenous chief subscribed "Innocenter," the other of a buccaneer killing a Spaniard, subscribed "Pro Peccatis" (Lat. "for the sins," Arnold 2007, 13; 18-20).

36. Ringrose's second narrative even incorporates a Spaniard's voice, presenting, in direct speech, the report of a Spanish captain, a "worthy gentleman" (74) whom the buccaneers have taken prisoner. Notably, however, the speech opens with the Spaniard's affirmation of the providential Protestant victory in the preceding battle: "I am now your prisoner at [sic] War by the over-ruling providence of fortune" (73).

37. Ringrose includes a paragraph in which he suggests the King of Darién to be "the true Lord of Panama and all the Country thereabouts" and the "Indians" "the true and natural Lords of the Country" (1685, 37), whose reign needs to be restored against the Spanish usurpers.

38. This claim is based on the journal Ayres published, which is perhaps the most humorous and least polished and scientific text of the pentalogy; it does not mask the prime motivation of Sharp's expedition: "That which 
often Spurs men on to the undertaking of the most difficult Adventures, is the sacred hunger of Gold; and 'twas Gold was the bait that tempted a Pack of merry Boys of us, ... being all Souldiers of Fortune ... to list our selves in the Service of one of the Rich West Indian Monarchs, the Emperour of Darien" (1684, 1-2). Throughout this text, it is the Darién Emperor who commands the troop (e.g., 74). Sharp himself, in contrast, implies that the only motivation of his expedition is the discovery of the South Seas (4); the other accounts place justice (against Spanish abuse) and patriotism as their prime motivation.

39. For detailed biographies of Dampier, cf. e.g. Bonner (1959) or Preston and Preston (2004).

40. On Dampier as a scientist, see also Shipman (1962).

41. The topic is touched upon by Edwards (1994, 31), albeit briefly in less than one paragraph. Mark Hanna's Pirate Nests and the Rise of the British Empire (2015) has discussed it in more detail.

42. Wafer's 'going native' is also mentioned by Dampier ("Mr. Wafer wore a Clout about him, and was painted like an Indian; and he was some time aboard before I knew him," 1699, 40).

43. On the topic of indigenous resistance through deception, tricksterism, and other tactics of creating unreliability, see e.g. Vizenor (1994, 88-89).

44. See also Exquemelin's refrain from authorial commentary after the relation of a Spaniard's story about an indigenous woman's intercourse with a lion-like animal ([1678] 1969, 111).

45. See also Silvio Torres-Saillant's Intellectual History of the Caribbean, in which he claims that creolization was fully engaged in Caribbean textualities as early as Francisco Balboa's Espejo de paciencia in 1608, countering Simon Gikandi and supporting Kamau Brathwaite's argument that the West Indies formed a "counter-renaissance" (2006, 149).

46. Execution sermons, a "splendid instrument for correcting the faults of [the] congregation" (Minnick 1968, 78), were directed to and sometimes preached at the request of condemned criminals briefly before they were hanged. On the genre, a substantial and serious contribution to the literature of colonial New England by highly educated ministers, see Minnick (1968), Crosby $(2010,5-8)$, or Bosco (whose essay especially focuses on the historical development of the execution sermon between 1674 and $1750 ; 1978)$. Bosco, following Perry Miller, regards the execution sermon as a form of jeremiad $(1978,162-63)$.

47. The title pages of three of these sermons do not bear Mather's name, but have been attributed to him by Mather bibliographer T. J. Holmes and by Charles Evans in his standard American Bibliography. For his 1717 sermon Instructions to the Living, from the Condition of the Dead, further certainty of authorship is established through Mather's Diary, which relates that the publication context of this recently held execution sermon would "render 
the Condition of the Pirates, lately executed, profitable" (1957, 490; note the ambiguity of spiritual and economic profitability). The Converted Sinner is also mentioned as desired for publication in the Diary (729).

48. For various perceived crises such as King Philip's War in early New England and their representations in writing, see Slotkin (1978, 3-42) or McWilliams, who also mentions the Half Way Covenant as one instance of a crisis scenario $(2004,13)$. Williams argues that " $[t]$ o be a New Englander, as these crises were historically understood, was to be in continuing, embattled protest against enemies both without and within" (14) and that thus overcoming crises served as central to New England identity formation.

49. Mather was much concerned with his own rule as the potential savior of condemned pirates. In Warnings to the Living, he alludes to the alleged mockery of Puritan ministers by pirates ("I am Credibly informed, That a principal Person among the Pirates now going to Day, upon the Gallows, was in one of his former Voyages, Flouting and Railing against a Minister in this place, who had never deserved it," 1704, 41), and in a diary entry of May 1724 confirms for himself his importance in the face of the fact that "One of the first Things which the Pyrates, who are now so much the Terror of them that haunt the Sea, impose on their poor Captives, is; To Curse $\mathrm{Dr} M$-": "The Pyrates now strangely fallen into the Hands of Justice here, make me the first Man, whose Visits and Councils and Prayers they beg for. Some of them under Sentence of Death, chuse to hear from me, the last Sermon they hear in the World" $(1957,729)$.

50. Another case in point would be William Hubbard (1621-1704), one of the more skeptical and rational ministers of a generation before Mather, who uses the image of the seaman in The Benefit of a Well-Ordered Conversation (1684; Elliott 1975, 152).

51. On the seventeenth-century Puritan imagination of the sea, see also Stein (1972).

52. The transnational nature of the pirate crews is also apparent in Mather's Instructions, as the condemned are all of different origins: two pirates are Dutch, two are Dutch-American, one is Jamaican, another a Swede, and yet another one a French Catholic who only speaks French (thus Mather talks to him in French and upon request of the bookseller adds a translation; 1717, 32-34).

53. Mather's choice of James 5, 20 for the frontispiece of The Converted Sinner (1724) is suggestive in this respect: "He who Converteth the Sinner from the Error of his way, shall save a soul from Death."

54. As Babette Levy diagnoses, Mather not only believed he "was cognizant of all the social and political evils in the society in which he lived but he also was certain that he ... was the one chosen to point out these evils and to correct them" $(1979,26)$. 
55. Notably, Mather also published The Sailours Companion and Counsellour. An Offer of Considerations for the Tribe of Zebulun; Awakening the Mariner to Think and Do Those Things That May Render His Voyage Prosperous in 1709, emphasizing the distinction between property rights as the pillar of society and its piratical transgression. For a brief discussion of this book of advice regarding the Lockean 'pursuit of property,' cf. McElroy (1935, 334-35).

56. In a footnote by the editor of the first edition of Mather's Diary (1912), Worthington Chauncey Ford, it is noted that the pirate captain who was killed in this affair was John Philips and may have been of Mather's first wife's Charleston family (1957, 722 n.2).

57. I use Benedict Anderson's term to highlight the imaginary nature of this conception of Puritan society.

58. On Puritan society as a theocratic oligarchy, cf. the classic materialist critique of Puritanism by James Truslow Adams, The Founding of New England (1922).

59. As Minnick asserts, the use of anecdotes is highly unusual for Cotton Mather, "who considered it criminal to demand more confirmation than the Word" (1968, 83): "About this he spoke apologetically, implying that a convention against such material existed among the ministry and perhaps in audiences, too"; he justified his use of these tales by saying they were appropriate for the occasion $(1704,41)$.

60. The form of direct address in execution sermons was taken over from the election sermon (Minnick 1968, 81).

61. For a detailed study of New England in the context of the British Atlantic world, see Conforti (2006).

62. Mather's diary relates to the publication context of The Converted Sinner in a March 1725 entry: "On Psal. CXIX. 104. Hating every false Way (On the Spectacle, which we have, in what the false Ways of our Pyrates, have brought them to.)" (1957, 787-88).

63. Mather emphasizes in both his diary and in the 1717 Instructions that he has tried to appeal to the governor on behalf of at least one of the pirates who was "not only more penitent, but also more innocent than the rest" (Mater 1957, 483), trying to save him from the gallows $(1717,19)$. His sermons allow for the possibility that even among the pirates there might have been some "Elect," explaining why some of them escaped death.

64. On the function of the sermon as a means for conversion or a "net of salvation," as Mather puts it in Manuductio ad Ministerium (1726a, 104), cf. Perry Miller's discussion in The New England Mind: The Seventeenth Century ([1939] 1961, 280-330).

65. Interestingly, Mather notes that the bookseller for whom he intended the work refused to print this sermon, but that other sellers desired it without his offering and printed no less than 1,200 copies. This might 
hint at the sensationalist appeal and attractiveness of piracy as a subject for publications beyond Mather's usual printers.

66. Already in Mather's Faithful Warnings of 1704 he uses such a continuum rather than polarity to condemn privateering, which "so easily degenerates into the Piratical; and the Privateering Trade, is usually carried on with so Unchristian a Temper, and proves an inlet unto so much Debauchery, and Iniquity, and Confusion, I believe, I shall have Good men Concur with me, in wishing, That Privateering may no more be practiced, except there may appear more hopeful Circumstances to Encourage it" (1704, 37). Other practices Mather locates on this continuum are fraud, cheating, lying, and the "Trade[s] of Sin" (46): idolatry, fortune-telling, prostitution and procuration, gaming and the lotteries; also, he condemns debt, bribery, lawyers pleading "Ill" cases, rulers who sell public offices, corruption, greed, and avarice. He closes his warnings by pointing to the "Riches of CHRIST" and to "Wisdom, the Merchandise whereof is better than the Merchandise of Silver, and the Gain therof than [unreadable word] Gold" (64).

67. Burnham's diagnosis also echoes Michael Kammen's seminal study of colonial America, People of Paradox: An Inquiry Concerning the Origins of American Civilization (1975). Kammen's fault lines, in contrast to the global vantage points of Burnham and others, however, often remain within an Old World/New World dichotomy of authoritarianism versus individualism, hierarchy versus mobility, or order versus chaos. Yet he acknowledges that there were both Old World continuities and transformations in America that occurred simultaneously $(1975,208)$. That Kammen characterizes colonial America as a "contrapuntal civilization" (273) highlights these paradoxes, but also evokes, through the musical metaphor, a harmonious whole that studies such as Burnham's have largely dismantled (see also my discussion of contrapuntal reading in the introduction).

68. An embedded narrative by a pirate similarly warns the congregation and readership to "[t]ake care against Spending your time Idly on the Sabbath Day, in staying at Home, or Walking of any other Diversions," advising them to rather "[d]iligently Frequent your Proper Places of Divine Worship, Respect your Pastors and Teachers, ... and pay the just Deference due to the Rulers, set over you by God" $(1717,33)$.

69. Mather's use of the vineyard in the same sermons that preach temperance as a response to the drinking habits of sailors and seafarers is itself somewhat ironical.

70. My title is taken from the second conversation between Mather and William Fly (1726b, 21).

71. The genderedness of these texts, portraying male criminals and addressing primarily the young men of Massachusetts, also marks a transition in 
the sense that earlier adventure narratives focused on the female captivity narrative (e.g., Mary Rowlandson's, 1682).

72. For The Vial Poured Out Upon the Sea (1726b), Mather uses an inscription from the book of Job $(24,19)$ that is the source for this discourse: "He is swift as the Waters; their Portion is cursed in the Eart; be beholdeth not the way of the Vineyards" (n.p.).

73. Cohen's brief examination of bookseller's advertisements for execution sermons in the Boston News-Letter shows that in the case of Mather's Instructions, the ad even omitted mention of the sermon altogether, emphasizing instead the pirates' shipwreck (1993, 10). It is noteworthy that the News-Letter featured 31 piracy stories in 1718 alone (Hanna $2015,374)$ and was thus another main site of the discursive construction of piracy in New England.

74. According to Manuel Schonhorn, editor of the Dover edition of the General History, Johnson (still thought to be a pseudonym of Daniel Defoe by Schonhorn) had no knowledge of either the Mather or Colman sermons, but used the trial protocols as the basis for his narrative.

75. The case of Captain John Quelch reports a similar behavior, as the publication of his and his crews' Dying Speeches demonstrates (see also Cohen 1993, 67).

76. In the second section of Mather's Useful Remarks, for instance, one pirate argues that he only joined the pirates with "the greatest Reluctancy, and Horror of Mind and Conscience"; "my Heart \& Mind Never Join'd in those Horrid Robberies, Conflagrations \& Cruelties Committed, so much as some have" $(1723,34)$.

77. Many accounts of piracy demonstrate that sailors who encountered pirates did not hesitate to join them, due to the better 'usage' they could expect among more egalitarian pirate crews.

78. See Bosco $(1978,159)$ and Cohen $(1993,16)$; the comparatively high rate of literacy in New England supported the wide circulation of these sermons. Daniel Cohen's study of New England crime literature between 1674 and 1860 presents one of the best overviews on these genres and their developments.

\section{Works Cited}

\section{Primary Sources}

A[yres], P[hilip], ed. 1684. The Voyages and Adventures of Capt. Barth. Sharp and Others, in the South Sea: Being a Journal of the Same. London: Printed by B.W. for R.H. and S.T. 
Colman, Benjamin. 1726. Mr. Colman's Sermon to the Pirates, July 10, 1726. It Is a Fearful Thing to Fall into the Hands of the Living God. A Sermon Preached to Some Miserable Pirates July 10, 1726. On the Lord's Day, Before Their Execution. To Which Is Added Some Account of Said Pirates. Boston: John Phillips and Thomas Hancock.

Dampier, William. 1697. A New Voyage Round the World. London: Printed for James Knapton.

Exquemelin, Alexander Olivier. (1678/1969) 2000. The Buccaneers of America. Translated by Alexis Brown. Mineola: Dover.

Mather, Cotton. 1700. The Religious Marriner. A Brief Discourse Tending to Direct the Course of Sea-Men, in Those Points of Religion, Which May Bring Them to the Port, of Eternal Happiness. Boston: B. Green, and J[ohn] Allen for Samuel Phillips.

- 1704. Faithful Warnings to Prevent Fearful Judgments: Uttered in a Brief Discourse, Occasioned, by a Tragical Spectacle, in a Number of Miserables Under a Sentence of Death for Piracy. At Boston in N.E. Jun. 22, 1704. Boston: Timothy Green.

- 1717. Instructions to the Living, from the Condition of the Dead: A Brief Relation of Remarkables in the Shipwreck of Above One Hundred Pirates, Who Were Cast Away in the Ship Whido, on the Coast of New-England, April 26, 1717. And in the Death of Six, Who After a Fair Trial at Boston, Were Convicted o Condemned, October 22. And Executed, November 15, 1717. With Some Account of the Discourse Had with Them on the Way to Their Execution. And a Sermon Preached on Their Occasion. Boston: John Allen for Nicholas Boone.

-1723. Useful Remarks. An Essay Upon Remarkables in the Way of Wicked Men. A Sermon on the Tragical End, unto Which the Way of Twenty-Six Pirates Brought Them; At New Port on Rhode-Island, July 19, 1723. With an Account of Their Speeches, Letters, \& Actions, Before Their Execution. London: T[imothy] Green.

- 1724. The Converted Sinner: The Nature of a Conversion to Real and Vital Piety: And the Manner in Which It Is to Be Pray'd o Striv'n for: A Sermon Preached in Boston, May 31, 1724. In the Hearing and at the Desire of Certain Pirates, a Little Before Their Execution: To Which There Is Added, A More Private Conference of a Minister with Them. Boston: Nathaniel Belknap.

- 1726a. Manuductio ad Ministerium. Boston: Thomas Hancock.

- 1726b. The Vial Poured Out Upon the Sea. A Remarkable Relation of Certain Pirates Brought Unto a Tragical and Untimely End. Some Conferences with Them, After Their Condemnation. Their Behaviour at Their Execution. And a Sermon Preached on That Occasion. Boston: T[homas] Fleet, for $\mathrm{N}$ [athaniel] Belknap.

- 1957. Diary of Cotton Mather. 2 vols. New York: Frederick Ungar. 
Ringrose, Basil. 1685. The Dangerous Voyage and Bold Attempts of Captain Bartholomew Sharp. Bucaniers of America: The Second Volume. London: Printed for William Crooke.

Sharp, Bartholomew. 1699. "Captain Sharp's Journal of His Expedition; Written by Himself." In A Collection of Original Voyages, edited by William Hacke, 1-55. London: Printed for James Knapton.

Wafer, Lionel. 1699. A New Voyage and Description of the Isthmus of America. London: Printed for James Knapton.

\section{SECONDARY Sources}

Antony, Robert J. 2007. Pirates in the Age of Sail: A Norton Casebook in History. New York: W. W. Norton.

Armitage, David. 2001. "The Red Atlantic." Review of The Many-Headed Hydra, by Peter Linebaugh and Marcus Rediker. Reviews in American History 29 (2001): 479-486.

Arnold, A. James. 2007. "From Piracy to Policy: Exquemelin's Buccaneers and Imperial Competition in 'America." Review: Literature and Arts of the Americas 40 (1): 9-20.

Barnes, Geraldine, and Adrian Mitchell. 2002. "Measuring the Marvelous: Science and the Exotic in William Dampier." Eighteenth-Century Life 26 (3): 45-57.

Bauer, Ralph. 2003. The Cultural Geography of Colonial American Literatures: Empire, Travel, Modernity. Cambridge: Cambridge University Press.

Baylin, Bernard. 1955. The New England Merchants in the Seventeenth Century. Cambridge: Harvard University Press.

Beeching, Jack. 2000. "Introduction." In The Buccaneers of America, by Alexander Olivier Exquemelin, translated by Alexis Brown, 7-20. Mineola: Dover.

Bolster, W. Jeffrey. 1997. Black Jacks: African American Seamen in the Age of Sail. Cambridge: Harvard University Press.

Bonner, Willard Hallam. 1959. Captain William Dampier: Buccaneer-Author. Some Account of a Modest Buccaneer and of English Travel Literature in the Eighteenth Century. London: Stanford University Press.

Boorstin, Daniel. 1958. The Americans: The Colonial Experience. New York: Random House.

Bosco, Ronald A. 1978. "Lectures at the Pillory: The Early American Execution Sermon." American Quarterly 30 (3): 156-176.

Brown, Richard D. 1989. Knowledge Is Power: The Diffusion of Information in Early America, 1700-1865. New York: Oxford University Press.

Burgess, Douglas R. Jr. 2014. The Politics of Piracy: Crime and Civil Disobedience in Colonial America. Lebanon: ForeEdge/University Press of New England. 
Burnham, Michelle. 2007. Folded Selves: Colonial New England Writing in the World System. Hanover: Dartmouth College Press/University Press of New England.

Campbell, Mel. 2011. "Pirate Chic: Tracing the Aesthetics of Literary Piracy." In Pirates and Mutineers of the Nineteenth Century: Swashbucklers and Swindlers, edited by Grace Moore, 11-22. Burlington: Ashgate.

Carey, Bev. 1997. The Maroon Story: The Authentic and Original History of the Maroons in the History of Jamaica, 1490-1880. Gordon Town: Agouti Press.

Castillo, Luis A. Diez. 1981. Los Cimarrones y Los Negros Antillanos en Panamá. 2nd ed. Panamá: Julio Mercado Rudas.

Clark, Steve. 1999. "Introduction.” In Travel Writing and Empire: Postcolonial Theory in Transit, edited by Steve Clark, 1-25. London: Zed Books.

Cohen, Daniel A. 1993. Pillars of Salt, Monuments of Grace: New England Crime Literature and the Origins of American Popular Culture, 1674-1860. Amherst: University of Massachusetts Press.

Conforti, Joseph A. 2006. Saints and Strangers: New England in British North America. Baltimore: Johns Hopkins University Press.

Craciun, Adriana. 2013. "Oceanic Voyages, Maritime Books, and Eccentric Inscriptions." Atlantic Studies 10 (2): 170-196.

Craton, Michael. 1997. Empire, Enslavement and Freedom in the Caribbean. Kingston: Ian Randle.

Crosby, Sara. 2010. "Early American Crime Writing." In The Cambridge Companion to American Crime Fiction, edited by Catherine Ross Nickerton, 5-16. Cambridge: Cambridge University Press.

Davidson, Cathy N. 2004. Revolution and the Word: The Rise of the Novel in America. Exp. ed. New York: Oxford University Press.

De Lourdes Edwards, Eva. 2007. "Linguistic Chaos in the 17th-Century Caribbean." La Torre 12 (46): 621-629.

Edwards, Philip. 1994. The Story of the Voyage: Sea Narratives in EighteenthCentury England. Cambridge: Cambridge University Press.

Elliott, Emory. 1975. Power and the Pulpit in Puritan New England. Princeton: Princeton University Press.

Fernández-Armesto, Felipe. 2003. The Americas: A Hemispheric History. New York: Modern Library.

Foucault, Michel. (1977) 1995. Discipline and Punish: The Birth of the Prison. New York: Vintage.

Franklin, H. Bruce. 1992. "Past, Present, and Future Seemed One." In Critical Essays on Herman Melville's "Benito Cereno," edited by Robert E. Burkholder, 230-246. New York: Hall.

Frohock, Richard. 2004. Heroes of Empire: The British Imperial Protagonist in America, 1596-1764. Newark: University of Delaware Press. 
. 2010a. "Common Mischaracterizations of Early English Translations of Exquemelin's Buccaneers of America." Notes and Queries 57: 506-508.

- 2010b. "Exquemelin's Buccaneers: Violence, Authority, and the Word in Early Caribbean History." Eighteenth-Century Life 34 (1): 56-72.

Gerassi-Navarro, Nina. 1999. Pirate Novels: Fictions of Nation Building in Spanish America. Durham: Duke University Press.

Gura, Philip. 1986-1987. "John Who? Captain John Smith and Early American Literature." Early American Literature 21 (3): 260-267.

Hanna, Mark G. 2015. Pirate Nests and the Rise of the British Empire, 15701740. Chapel Hill: University of North Carolina Press.

Hartog, François. 1988. The Mirror of Herodotus: The Representation of the Other in the Writing of History. Translated by Janet Lloyd. Berkeley: University of California Press.

Hazard, Paul. 1953. The European Mind (1680-1715). Translated by J. Lewis May. London: Hollins \& Carter.

Hebel, Udo. 2004. "Survival Without Seasickness: Cotton Mather's Miniature Anthology of Sea Deliverance Narratives in Magnalia Christi Americana." In The Sea and the American Imagination, edited by Klaus Benesch, Jon-K. Adams, and Kerstin Schmidt, 15-36. Tübingen: Stauffenburg.

Hill, Christopher. 1984. "Radical Pirates?" In The Origins of Anglo-American Radicalism, edited by Margaret and James Jacob, 17-32. London: George Allen \& Unwin.

Hobsbawm, Eric. (1959) 1963. Primitive Rebels: Studies in Archaic Forms of Social Movements in the 19th Century. Manchester: Manchester University Press.

- (1969) 2000. Bandits. London: Abacus.

Howse, Derek, and Norman J. W. Thrower. 1992. "Introduction." In A Buccaneer's Atlas: Basil Ringrose's South Sea Waggoner, a Sea Atlas and Sailing Directions of the Pacific Coast of the Americas, 1682, edited by D. Howse and N. J. W. Thrower, 1-33. Berkeley: University of California Press.

Hulme, Peter. 1986. Colonial Encounters: Europe and the Native Caribbean 1492-1797. London: Routledge.

Irving, Sarah. 2007. "An Empire Restored: America and the Royal Society of London in the Restoration." In America in the British Imagination, edited by Catherine Armstrong, Roger Fagge, and Tim Lockley, 27-47. Newcastle: Cambridge Scholars.

Johns, Adrian. 2009. Piracy: The Intellectual Property Wars from Gutenberg to Gates. Chicago: Chicago University Press.

Joyce, L. E. Elliott. 1934. "Lionel Wafer and His Times." In A New Voyage and Description of the Isthmus of America, edited by L. E. E. Joyce, xi-lxvii. N.P.: The Hakluyt Society. 
Kammen, Michael. 1975. People of Paradox: An Inquiry Concerning the Origins of American Civilization. New York: Alfred A. Knopf.

Karremann, Isabel. 2011. “The Sea Will Make a Man of Him?' Hypervirility, Effeminacy, and the Figure of the Queer Pirate in the Popular Imagination from the Early Eighteenth-Century to Hollywood." Historical Masculinities as an Intersectional Problem. Special issue, Gender Forum 32. http://genderforum.org/historical-masculinities-as-an-intersectional-pro blem-issue-32-2011/.

Kauders, Hans. 1926. "Zur Einführung." In A.O. Exquemelin, Die Amerikanischen Seeräuber. Ein Flibustierbuch aus dem XVII. Jabrbundert, edited and translated by H. Kauders, n.p. Erlangen: Verlag der philosophischen Akademie.

Kempe, Michael. 2010. Fluch der Weltmeere. Piraterie, Völkerrecht und internationale Beziehungen, 1500-1900. Frankfurt am Main: Campus.

Krise, Thomas W. 1999. "Introduction.” In Caribbeana: An Anthology of English Literature of the West Indies, 1657-1777, edited by Thomas W. Krise, 1-15. Chicago: University of Chicago Press.

Kuhn, Gabriel. 2010. Life Under the Jolly Roger: Reflections on Golden Age Piracy. Oakland: PM Press.

Lane, Kris. 2007. "The Life and Times of William Dampier: An Introduction." In William Dampier: A New Voyage Round the World, n.p. Warwick: 1500 Books.

Langewiesche, William. 2004. The Outlaw Sea: A World of Freedom, Chaos, and Crime. New York: North Point Press.

Latimer, Jon. 2009. Buccaneers of the Caribbean: How Piracy Forged an Empire. Cambridge: Harvard University Press.

Lévi-Strauss, Claude. (1964/1966) 1983. The Raw and the Cooked. Mythologies 1. Translated by John and Doreen Weightman. Chicago: University of Chicago Press.

Levy, Babette Y. 1979. Cotton Mather. Boston: Twayne.

Linebaugh, Peter, and Marcus Rediker. 2000. The Many-Headed Hydra: Sailors, Slaves, Commoners, and the Hidden History of the Revolutionary Atlantic. Boston: Beacon Press.

Mackenthun, Gesa. 2013. "Imperial Archaeology: The American Isthmus as Contested Scientific Contact Zone." In Surveying the American Tropics: A Literary Geography from New York to Rio, edited by Maria Cristina Fumagalli, Peter Hulme, Owen Robinson, and Lesley Wylie, 101-130. Liverpool: Liverpool University Press.

Mackie, Erin. 2009. Rakes, Highwaymen, and Pirates: The Making of the Modern Gentleman in the Eighteenth Century. Baltimore: Johns Hopkins University Press. 
McElroy, John William. 1935. "Seafaring in Seventeenth-Century New England." New England Quarterly: A Historical Review of New England Life and Letters 8 (3): 331-364.

McWilliams, John. 2004. New England's Crises and Cultural Memory: Literature, History, Politics, Religion 1620-1860. Cambridge: Cambridge University Press.

Miller, Perry. (1939) 1961. The New England Mind: The Seventeenth Century. Boston: Beacon Press.

Minnick, Wayne, C. 1968. “The New England Execution Sermon, 1639-1800.” Speech Monographs 35 (1): 77-89.

Motohashi, Ted. 1999. "The Discourse of Cannibalism in Early Modern Travel Writing." In Travel Writing and Empire: Postcolonial Theory in Transit, edited by Steven H. Clark, 83-99. London: Zed Books.

Munter, Robert, and Clyde L. Grose, eds. 1986. Englishmen Abroad: Being an Account of Their Travels in the Seventeenth Century. Lewiston: Edwin Mellen Press.

Muth, Verena. 2011. "Bukaniere und der Isthmus von Darién im 17. Jahrhundert." MATICES: Zeitschrift zu Lateinamerika, Spanien und Portugal 18: 28-30.

Neill, Anna. 2002. British Discovery Literature and the Rise of Global Commerce. New York: Palgrave.

Ordahl Kupperman, Karen, ed. 1995. America in European Consciousness, 14931750. Chapel Hill: University of North Carolina Press.

Ouellet, Réal. 2004. "Lahontan et Exquemelin: deux exemples de dérive textuelle (XVIIe-XVIIIe siècles)." Tangence 74: 45-57.

Payton, Jason M. 2013. "Alexander Oliver Exquemelin's The Buccaneers of America and the Disenchantment of Imperial History." Early American Literature 48 (2): 337-365.

Pérotin-Dumon, Anne. 1991. "The Pirate and the Emperor: Power and the Law on the Seas, 1450-1850." In The Political Economy of Merchant Empires, edited by James D. Tracy, 196-227. Cambridge: Cambridge University Press.

Peterson, Mark A. 1997. The Price of Redemption: The Spiritual Economy of Puritan New England. Stanford: Stanford University Press.

Powell, Philip Wayne. (1971) 2008. Tree of Hate: Propaganda and Prejudices Affecting United States Relations with the Hispanic World. 2nd ed. Albuquerque: University of New Mexico Press.

Pratt, Mary Louise. (1992) 2008. Imperial Eyes: Travel Writing and Transculturation. London: Routledge.

Preston, Diana and Michael Preston. 2004. A Pirate of Exquisite Mind: Explorer, Naturalist and Buccaneer-The Life of William Dampier. New York: Walker \& Co. 
Rediker, Marcus. 2004. Villains of All Nations: Atlantic Pirates in the Golden Age. Boston: Beacon Press.

Rennie, Neil. 2013. Treasure Neverland: Real and Imaginary Pirates. Oxford: Oxford University Press.

Richetti, John J. (1969) 1992. Popular Fiction Before Richardson: Narrative Patterns 1700-1739. Oxford: Clarendon Press.

Ronald, Susan. 2007. The Pirate Queen: Elizabeth I, Her Pirate Adventures, and the Dawn of Empire. New York: HarperCollins.

Shapiro, Barbara J. 1983. Probability and Certainty in Seventeenth-Century England: A Study of the Relationships Between Natural Science, Religion, History, Law, and Literature. Princeton: Princeton University Press.

Sherman, William H. 2002. "Stirrings and Searchings (1500-1720)." In The Cambridge Companion to Travel Writing, edited by Peter Hulme and Tim Youngs, 17-36. Cambridge: Cambridge University Press.

Shipman, Joseph C. 1962. William Dampier, Seaman-Scientist. Lawrence: University of Kansas Libraries.

Slotkin, Richard. 1978. "Introduction." In So Dreadfull a Judgment: Puritan Responses to King Philip's War, 1676-1677, edited by R. Slotkin and James K. Folsom, 3-45. Middletown: Wesleyan University Press.

Stein, Roger B. 1972. "Seascape and the American Imagination: The Puritan Seventeenth Century." Early American Literature 7 (1): 17-37.

Stout, Harry S. 1986. The New England Soul: Preaching and Religious Culture in Colonial New England. New York: Oxford University Press.

Taussig, Michael. 1993. Mimesis and Alterity: A Particular History of the Senses. New York: Routledge.

Thomson, Janice E. 1994. Mercenaries, Pirates, and Sovereigns: State-Building and Extraterritorial Violence in Early Modern Europe. Princeton: Princeton University Press.

Torres-Saillant, Silvio. 2006. An Intellectual History of the Caribbean. New York: Palgrave Macmillan.

Vizenor, Gerald. 1994. Manifest Manners: Narratives on Postindian Survivance. Lincoln: University of Nebraska Press.

Wharton, Donald P. 1992. "Hudson's Mermaid: Symbol and Myth in Early American Sea Literature." In Early American Literature and Culture: Essays Honoring Harrison T. Meserole, edited by Kathryn Zabelle Derounian-Stodola, 38-56. Newark: University of Delaware Press.

Williams, Daniel E. 1983. "Rogues, Rascals and Scoundrels: The Underworld Literature of Early America." American Studies 24 (2): 5-19.

- 1986. “Behold a Tragic Scene Strangely Changed into a Theater of Mercy': The Structure and Significance of Criminal Conversion Narratives in Early New England.” American Quarterly 38 (5): 827-847. 
1987. "Puritans and Pirates: A Confrontation Between Cotton Mather and William Fly in 1726." Early American Literature 22: 233-251.

- 1993a. "Introduction." In Pillars of Salt: An Anthology of Early American Criminal Narratives, edited by Daniel Williams, 1-63. Madison: Madison House Publishers.

- 1993b. "Preface." In Pillars of Salt: An Anthology of Early American Criminal Narratives, edited by Daniel Williams, x-xiii. Madison: Madison House Publishers.

Wolf, Eric R. 1982. Europe and the People Without History. Berkeley: University of California Press.

Open Access This chapter is licensed under the terms of the Creative Commons Attribution 4.0 International License (http://creativecommons.org/licenses/ by $/ 4.0 /$ ), which permits use, sharing, adaptation, distribution and reproduction in any medium or format, as long as you give appropriate credit to the original author(s) and the source, provide a link to the Creative Commons license and indicate if changes were made.

The images or other third party material in this chapter are included in the chapter's Creative Commons license, unless indicated otherwise in a credit line to the material. If material is not included in the chapter's Creative Commons license and your intended use is not permitted by statutory regulation or exceeds the permitted use, you will need to obtain permission directly from the copyright holder.

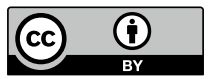

